Article

\title{
The River as an Economic Asset: Settlement and Society in the Xeros Valley in Cyprus
}

\author{
Giorgos Papantoniou *(D) and Athanasios K. Vionis * \\ Department of History and Archaeology, University of Cyprus, P.O. Box 20537, 1678 Nicosia, Cyprus \\ * Correspondence: papantoniou.giorgos@ucy.ac.cy (G.P.); vionis@ucy.ac.cy (A.K.V.)
}

Received: 28 October 2018; Accepted: 26 November 2018; Published: 13 December 2018

\begin{abstract}
Settled and Sacred Landscapes of Cyprus (SeSaLaC) is a systematic archaeological survey project of the University of Cyprus in the Xeros River valley in the Larnaka district in Cyprus. This article aims to present a first synthesis of the diachronic settlement pattern in the region. After a short introduction on the area and the SeSaLaC project, we attempt to identify and interpret settlement evolution and landscape changes in the region, from early prehistory to Late Antiquity. The contextualisation and evaluation of settlement changes in the Xeros River valley are carried out within a multi-layered framework along the main strands of approach presented in this Land special issue. The presentation and analysis that follows below is a work in progress.
\end{abstract}

Keywords: Cyprus; landscape archaeology; surface survey; river valley; settlement organisation

\section{Introduction: Settled and Sacred Landscapes of Cyprus (SeSaLaC)}

SeSaLaC is a multi-period surface survey project led by the University of Cyprus in the Xeros River valley, 2500 ha in size, situated $20 \mathrm{~km}$ southwest of Larnaka and $5 \mathrm{~km}$ inland from the south coast of Cyprus in the Larnaka district (Figure 1). The project aims to identify, map, and interpret traces of pre-modern human activity in the valley in order to examine the interaction of secular and religious space with the natural environment. A range of informed methods of intensive field survey has been employed, such as the systematic counting of pottery densities in transects running north-south throughout our survey area, aerial photography, micro-topographical surveys, and the in-situ digital recording of archaeological information and monuments, using the technical equipment of the Artefact and Landscape Studies Laboratory (ArtLandS Lab). The transects plotted throughout the Xeros valley comprise continuous zones of $150 \mathrm{~m}$ in width at $150 \mathrm{~m}$ intervals; walkers lined up within each transect-unit $(150 \times 150 \mathrm{~m})$ were spaced $15 \mathrm{~m}$ from one another and recorded the number of surface ceramics and lithics, architectural remains, and surface visibility with the aim of identifying unknown archaeological sites. Non-surveyed sectors in the Xeros comprise built-up areas (e.g., present-day villages and the highway), fenced private property, thickly-vegetated grounds and/or natural barriers (e.g., the Xeros River, streams, steep slopes, etc.). Identified sites were gridded at the following stage into $25 \times 25 \mathrm{~m}$ squares, and a finer survey was conducted by a group of field-walkers spaced at $5 \mathrm{~m}$ from one another. The largest site in size located at the heart of our survey area, mostly dated to the Late Antique era (i.e., Kophinou-Panagia, discussed below), was surveyed during the first season of the project in 2014 in a field-by-field manner, with walkers spaced at $5 \mathrm{~m}$ intervals. 


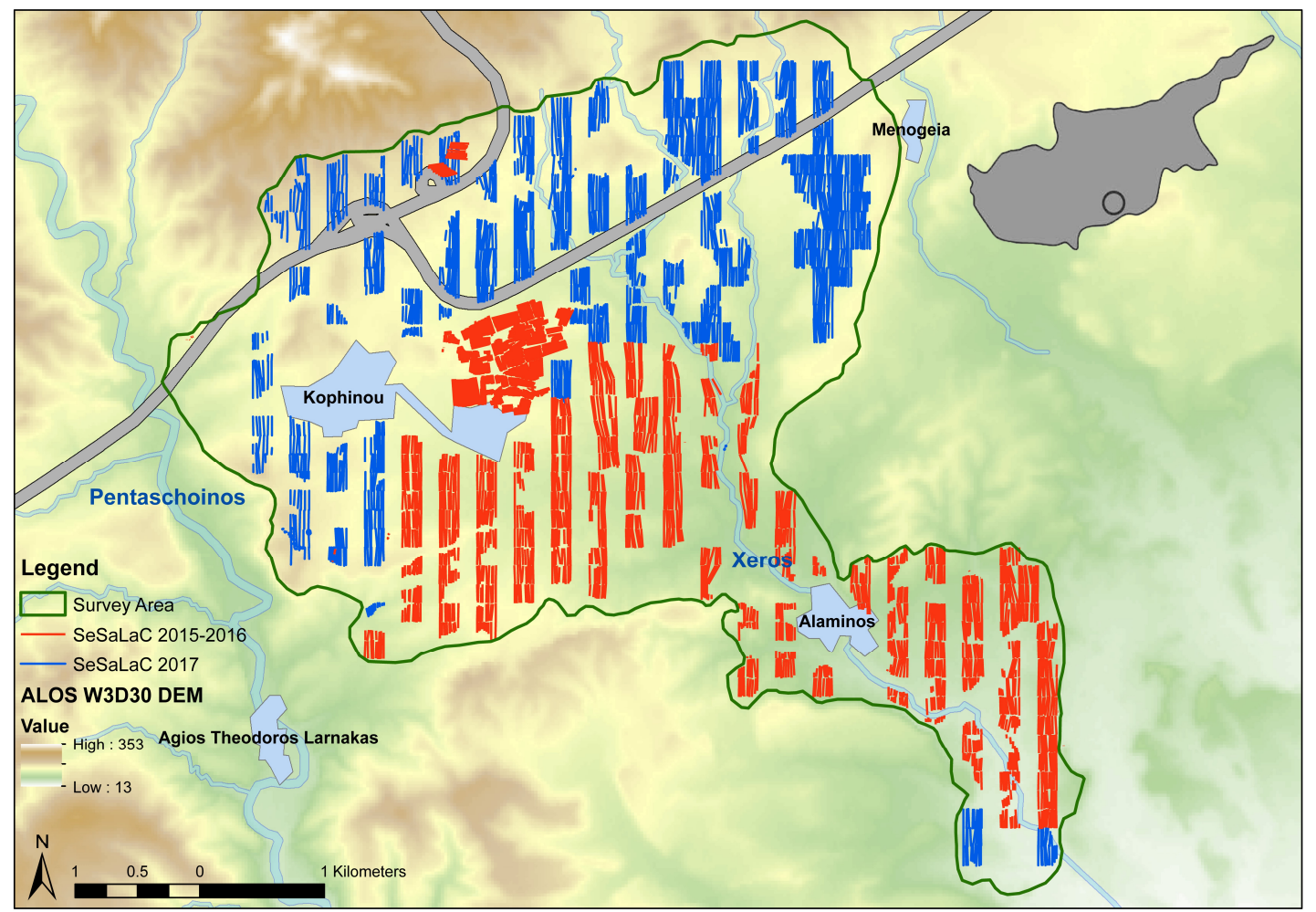

Figure 1. SeSaLaC surface survey area with transects (zones of squares: $150 \times 150 \mathrm{~m}$ ) investigated in 2015-2016 and 2017. ALOS DEM are in metres. Digital data courtesy of the Geological Survey Department, Republic of Cyprus (Map by Charalambos Paraskeva).

Surface material evidence of ancient rural activities in our region includes contemporary agricultural terraces, impenetrable hilly areas, and visible archaeological features, but this activity is represented mainly by poorly preserved pottery. Thus, the identification and the subsequent distinction amongst different types of rural settlement pose challenges for the regional survey [1-3]. We very much base our research on the spatial analysis of settlements that emphasise location in association with natural resources (mainly soil and land types, copper mines, and water availability). In these attempts, Geographic Information Systems (GIS) have proved to be very useful, and their employment has assisted us in contextualising rural sites within their habitation and economic frameworks, maintaining in mind, at the same time, the problems around their deterministic nature (cf. [4] (p. 552, with references) [5] (pp. 149-150).

The village of Kophinou at the centre of the survey area (Figure 1) lies nowadays in a landscape almost devoid of recent development and is archaeologically a terra incognita. The survey area is located today at a major junction of the island's motorway, linking the capital Nicosia with the towns of Larnaka to the southeast, Limassol on the south coast and Paphos to the west. Its location on the edge of two or three Iron Age polity territories (for the discussion on the problem of co-existence of Idalion and Kition as independent polities, see [6] (pp. 33-34)), its immediate proximity to the major infrastructure of the Roman road network, its selection as one of the most strategic enclaves of the Turkish Cypriots in the 1960s and, nowadays, the establishment of the only governmental Reception Centre for Asylum Seekers in Cyprus at Kophinou (hosting refugees from Syria), confirm the centrality of this un-central rural landscape diachronically. As we explain 'centrality' in the introductory article of this Land Special Issue, we view first Alaminos-Kambos, and later Kophinou-Panagia as 'central places' within their micro-regions, related to a hierarchical system of settled spaces, environmental, and topographical parameters, the availability of and control over natural resources and the construction of dependent territories around them. In many respects, the microenvironment of the survey area, defined by a 
continuous series of hills, crossed by the Xeros River, and located within the 'landward buffer' of Cyprus, provides an ideal laboratory for examining settlement systems in the longue durée.

\section{Settlements Systems in the Xeros Valley from Prehistory to Late Antiquity}

Xeros (meaning the 'dry river' in Greek), or Xeropotamos as some locals call it, stems from the area west of the Stavrovouni Mountain and flows into the sea, a few meters away from the modern yacht shelter in Alaminos. The river creates a fertile valley along its way, where people from antiquity to this day used a canalisation system to water their orchards. Preliminary GIS mapping of the agricultural soils and settlement activity [7] (Figure 2) has shown that the main settlements lie in the middle of less fertile soils; this should probably be seen as a very wise choice on behalf of its inhabitants, making use of less productive areas for their settlements' built space, as well as for less demanding cultivations, such as vegetable gardens and olive groves or as pasture land. In addition, the region immediately north of the Xeros River valley is within the copper zone of the Troodos ophiolite (Figure 3); however, the good quality mines (pillow lavas and basal group formations richer in copper) are actually located on the other side of the Troodos Mountain range at Mathiatis, as evidenced also by the archaeological evidence [4] (p. 543, figure 1).

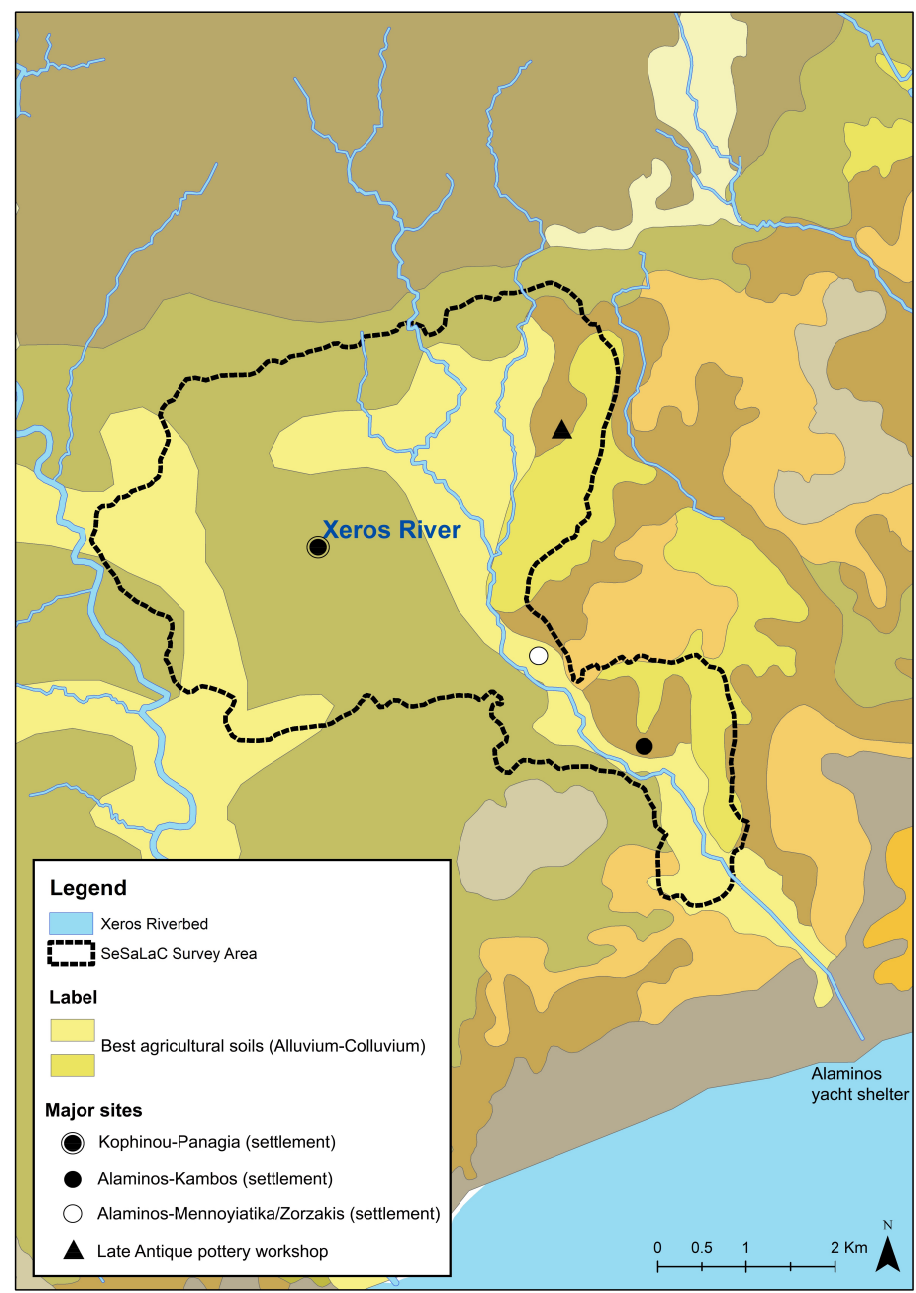

Figure 2. Best agricultural soils in the Xeros River valley according to the Soil Atlas of Europe and the relation of the Late Antique site of Kophinou-Panagia and the Early-Middle Bronze Age settlement of Alaminos-Kambos with their surrounding agricultural territory. Digital data courtesy of the Geological Survey Department, Republic of Cyprus (Map by Charalambos Paraskeva). 
Our team is already investigating how environmental changes and/or tectonic activity may have contributed to riverbed shifting, and how these may have affected people and settlement activity diachronically. Interviews of our team with the locals inform us that even a few decades ago, the Xeros was not as dry as it is today; quite the opposite, locals remember running water in the Xeros, reaching its full capacity. We hope that the upcoming geological study by our team (still in progress) will further clarify this picture. In addition, funding and findings permitting, geoarchaeological (and maybe osteological) studies in the future may reveal whether the region and its people, at specific times, went through particular physical stress.

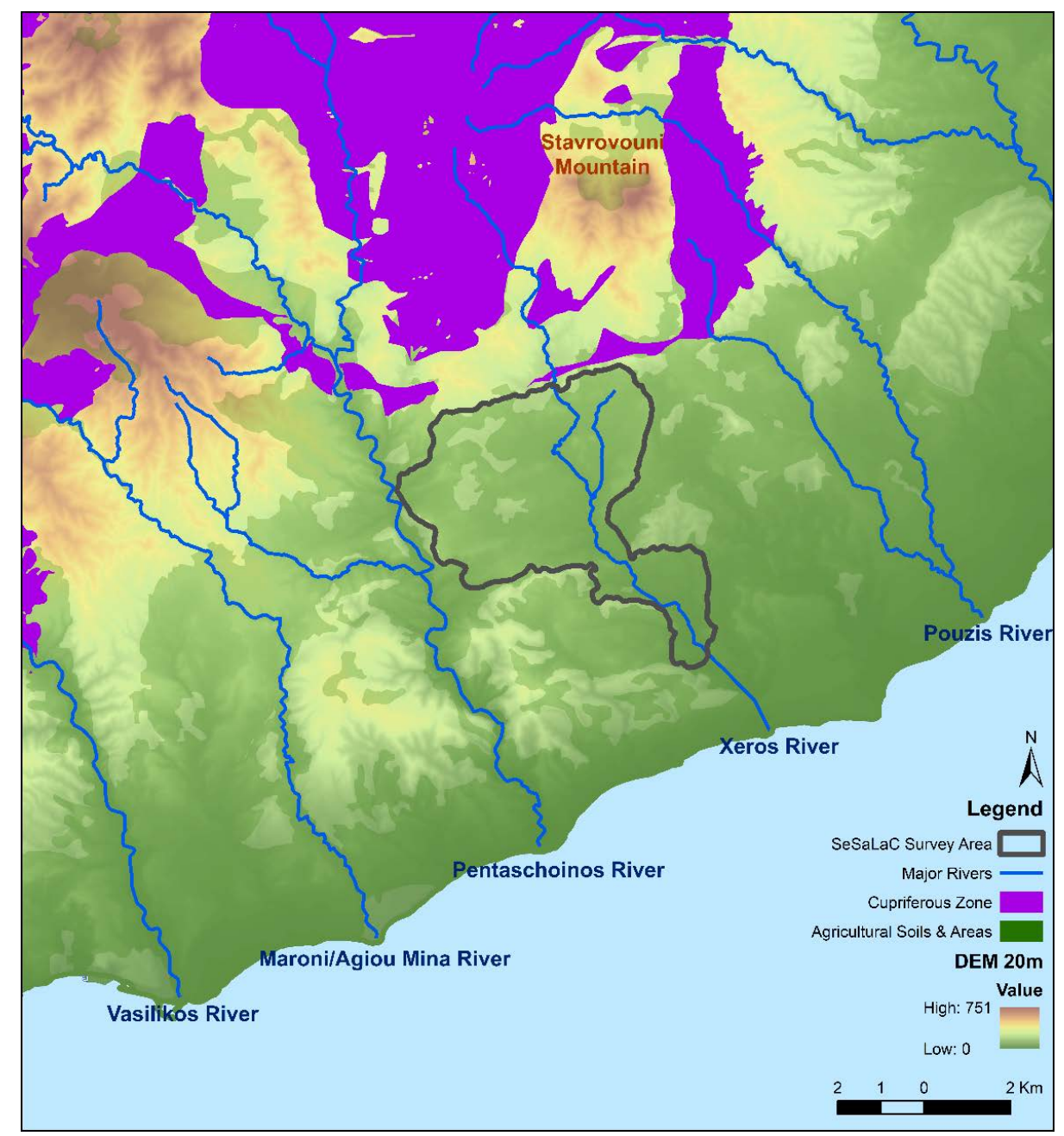

Figure 3. Regional map with the SeSaLaC survey area, major rivers, cupriferous zone, and agricultural soils and areas. Digital data courtesy of the Geological Survey Department, Republic of Cyprus (Map by Charalambos Paraskeva).

Future research should also integrate survey data with geological investigation, considering that some rivers along the southeast coast may (at least seasonally and/or simply via land routes) relate with a system of identified anchorages, used in conjunction with overland portages for transporting timber, copper, and other goods downstream to the coast for processing and cabotage [8] (cf. [9-11]). Although there is no evidence for built harbours, A. Bernard Knapp notes that several potential harbourages have been identified along the south coast between Palaipaphos and Hala Sultan Tekke [12] (pp. 139-140, with references), including Alaminos-Latourou Chiftlik [12] (p. 3, figure 2). While the international maritime connectivity of Cyprus diachronically has been emphasised on various occasions, we still lack a solid methodology for approaching coastscapes (encompassing the shoreline, the coastal lowlands and the communication routes with the hinterland) and small-scale, regional interaction; the work of 
another project west of our area, in the nearby Maroni and Vasilikos valleys, shed further light on these south-central coastscapes $[13,14]$ (with references). We also hope to be able to integrate geophysics and other disciplines into our study area in the future: The integration of zooarchaeology, archaeobotany and ethnoarchaeology in Cyprus, for example, has recently shown that not only the adaptation of sheep and goat management to differences in vegetation and landscape locally, but also that other elements in the landscape, such as wells, springs, rivers, pools of fresh water and safe access points to the sea, are integral parts of herd management [15].

For the remainder of this contribution, however, let us first focus on the results of our fieldwork in the valley, contextualising the diachronic settlement pattern from prehistory to Late Antiquity. The contextualisation and evaluation of settlement-change in the Xeros River valley is carried out within a multi-layered framework or along five main strands of approach: (a) Siedlungskammer or 'Settlement Chambers', (b) 'Central Place Theory' and settlement hierarchies, (c) 'Ecosystems' and land-use, (d) 'Sacred Landscapes' and (e) 'Political Economy' [16] (with references).

\subsection{Before the Early Bronze Age}

Apart from a small concentration of lithics that remains at present undated (Figure 4), but could potentially extend back to the Aceramic Neolithic (ca. 9000-5200 BC), the earliest more securely (based on pottery fragments) dated evidence for human presence in the Xeros River valley belongs to the Late Neolithic (ca. 5200-4000) (these early phases, up to the end of the Bronze Age, are currently under study by the member of our research team Charalambos Paraskeva). The site of Kophinou-Kophinos, on a hill north-east of Kophinou, may be the earliest site (probably a settlement) identified in our area of research so far.
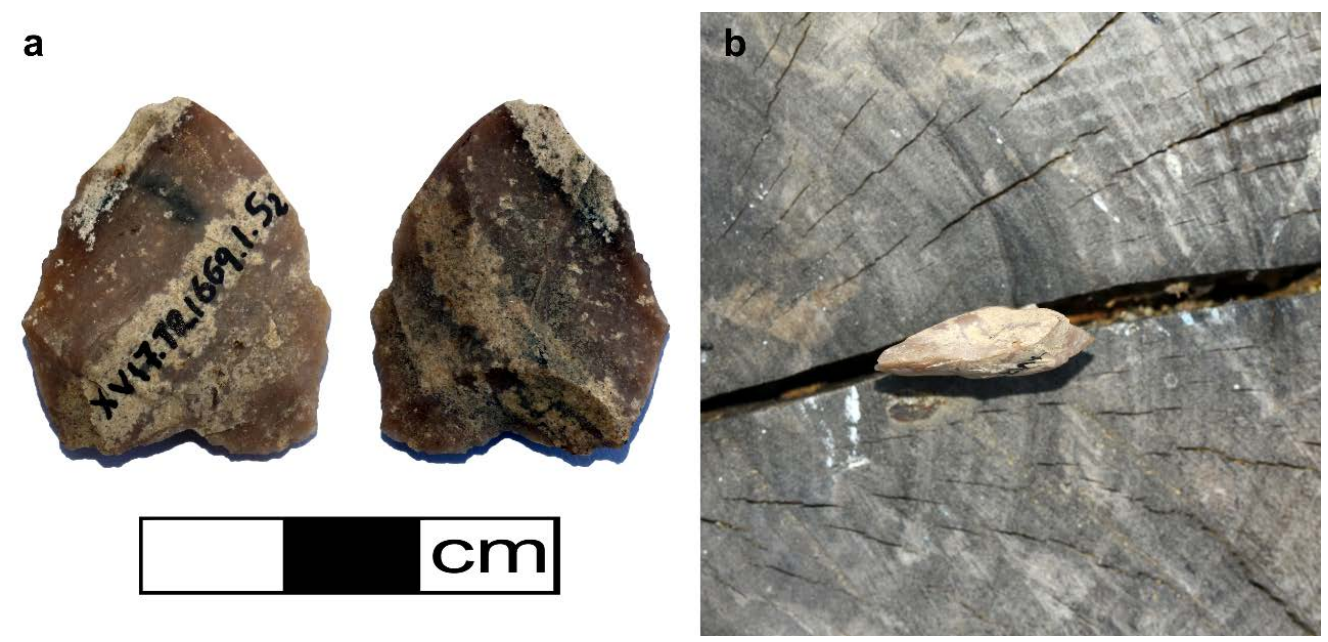

Figure 4. Lithics currently under study: (a) Arrowhead on both sides; (b) arrowhead side-view on tree-trunk stump (Images by Charalambos Paraskeva).

The site of Alaminos-Mennoyiatika/Zorzakis is the only Chalcolithic settlement site identified in our survey area. Our team relocated the site based on information from the late Porphyrios Dikaios (former Director of the Department of Antiquities, Republic of Cyprus), who conducted surface collection and trial excavations at the site back in 1936 (Figures 2 and 5). The site dates to the Middle Chalcolithic period (ca. 3500-2900/2800 BC) and is located at the narrow passage that opens into the valley of Alaminos, on the eastern bank of the Xeros River (personal communication with C. Paraskeva, 23 September 2018; cf. [17-19]. During sanitation works for the construction of a house, our team recently identified and recorded the remains of a floor from a Chalcolithic roundhouse with evidence for a hearth, pottery and stone tools protruding from the section (Figure 6). Sites dating to this period, such as Kissonerga-Mosfilia, Lemba-Lakkous, Souskiou-Laona, and Erimi-Bamboula in west or south Cyprus, have been systematically excavated [20] (pp. 206-215, with full lists of the 
publications for each excavation) [21] (pp. 83-118). While this may partly result from the fact that other projects east of Xeros may have not always included specialists on the Chalcolithic period, AlaminosMennoyiatika/Zorzakis remains the easternmost known Chalcolithic site on the island to date.

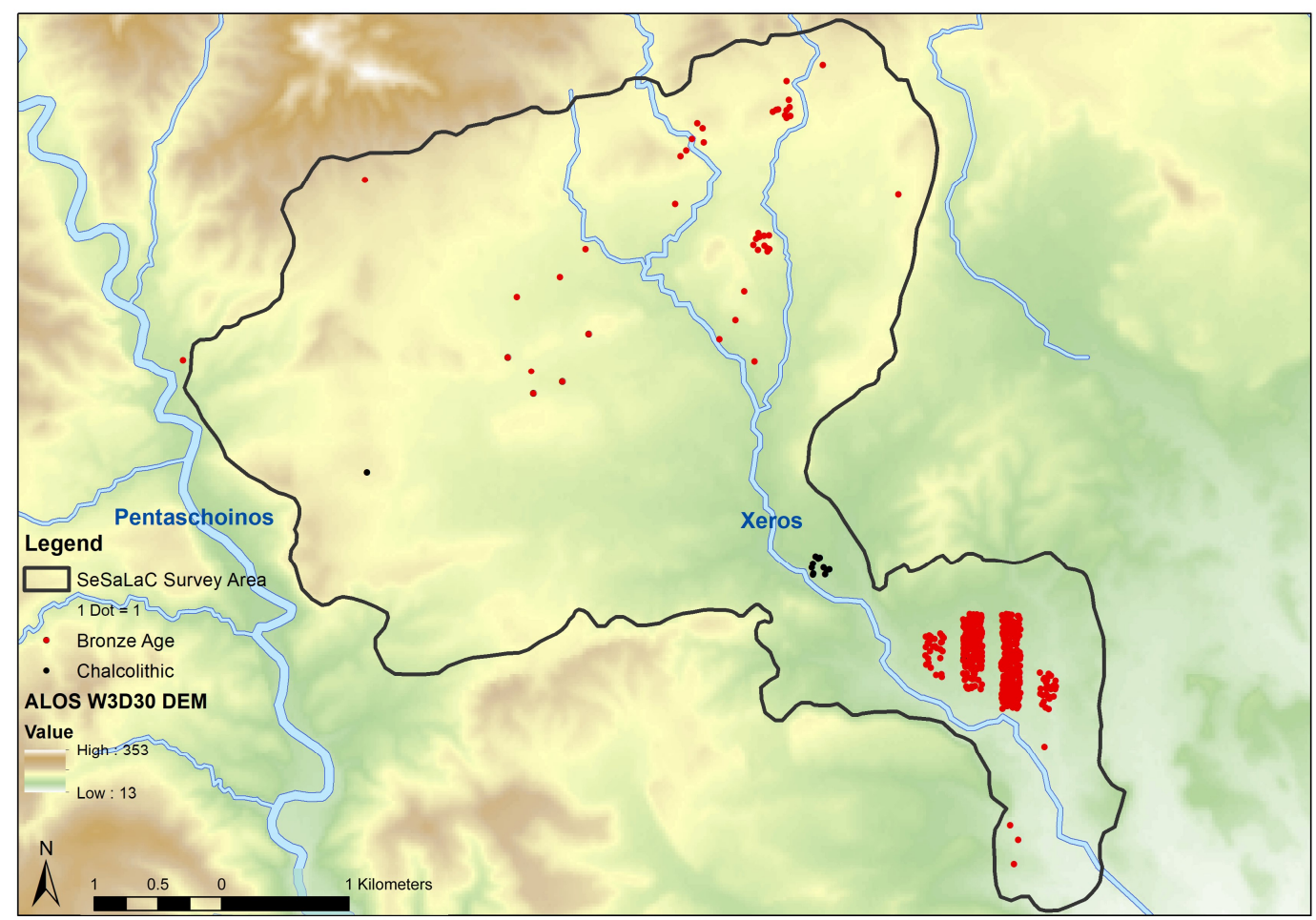

Figure 5. Chalcolithic and Bronze Age pottery distribution. ALOS DEM are in metres. Digital data courtesy of the Geological Survey Department, Republic of Cyprus (Map by Charalambos Paraskeva).

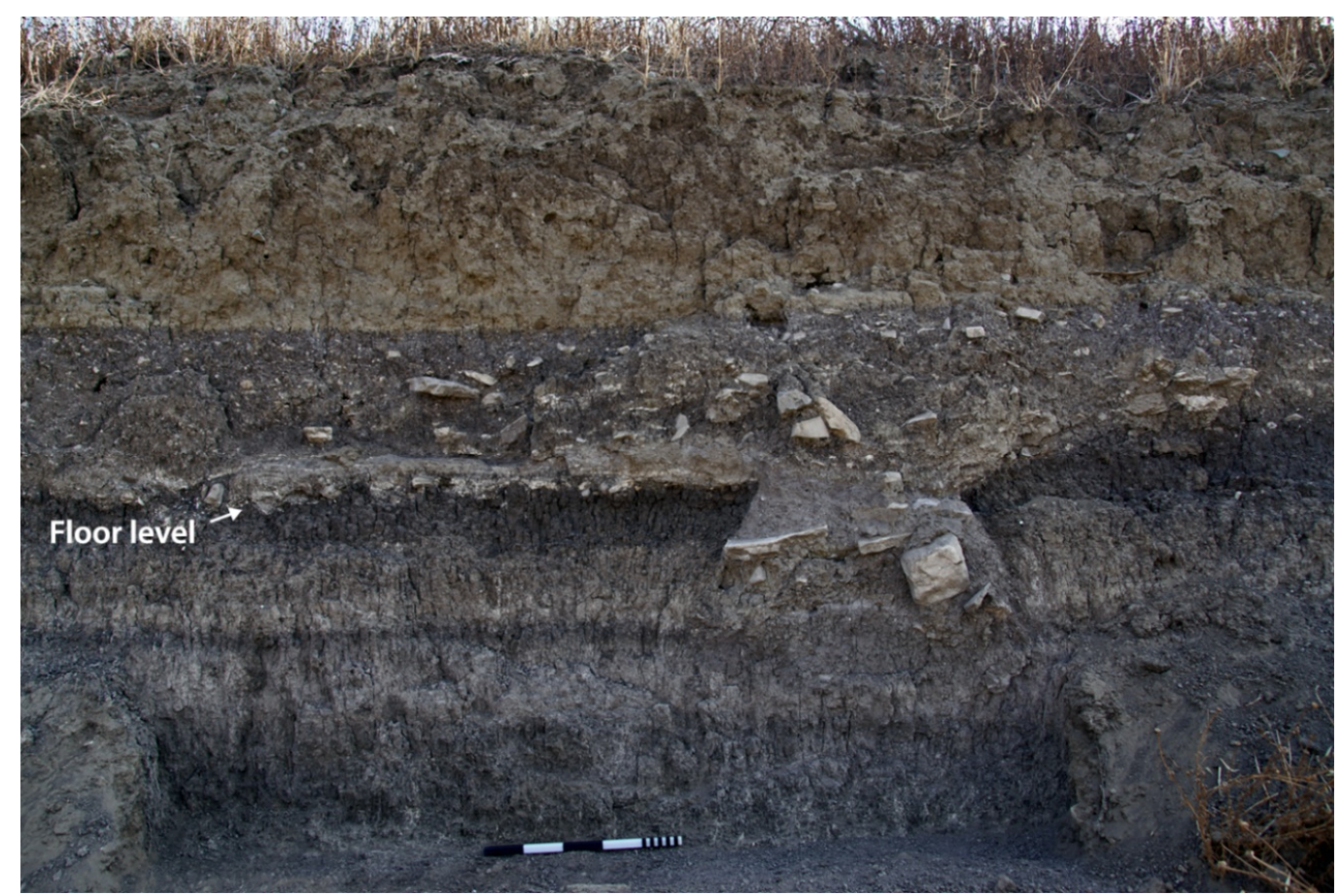

Figure 6. The remains of a Middle Chalcolithic floor, most probably belonging to a Chalcholithic house (Image by Charalambos Paraskeva). 


\subsection{Early and Middle Bronze Age}

The Department of Antiquities of the Republic of Cyprus had previously undertaken the excavation of trenches at the site of Alaminos-Kambos unearthing stratified pottery of the Early (ca. 2250/2200-2000/1950 BC) and Middle (ca. 2000/1950-1680/1650 BC) Bronze Age, some walls, and floor installations [22] (pp. 90-91), (cf. [23] (pp. 445-446)). In addition, following an accidental discovery, the Department of Antiquities excavated an intact Early Bronze Age tomb south of the settlement, where a skeleton and 7 well-preserved Red Polished Ware vessels were recovered (Figure 7). Our systematic survey in the Xeros River valley has identified Early and Middle Bronze Age evidence for intensive settlement activity south and east of the medieval tower of Alaminos at this site (Figure 8). The dense concentration of pottery, accounting for more than 700 sampled potsherds (Figure 5) dated to the period (and many more counted in the survey transects of the site), together with other artefacts, such as millstones and grinding tools (Figure 9), suggests the presence of an enormous settlement. The maximum spread of material is ca. $70 \mathrm{ha}$, but it is not yet clear as to whether the concentration represents a site, multiple clusters of a site, moving households within the site at different phases of the long Early-Middle Bronze Age, or a central site with satellite cemeteries (for problems in site estimates in Late Bronze Age Cyprus however, see [24] (esp. pp. 13-16)). The possibility of initiating a geophysical prospection at Alaminos-Kambos may help us further clarify the situation. Moreover, we identified a small group of looted tombs along one of the streams of the Xeros River, on the easternmost edge of the site. In accordance with other Cypriot Early and Middle Bronze Age sites, cemeteries of the period seem to be located outside the settlement, usually on nearby hillsides.

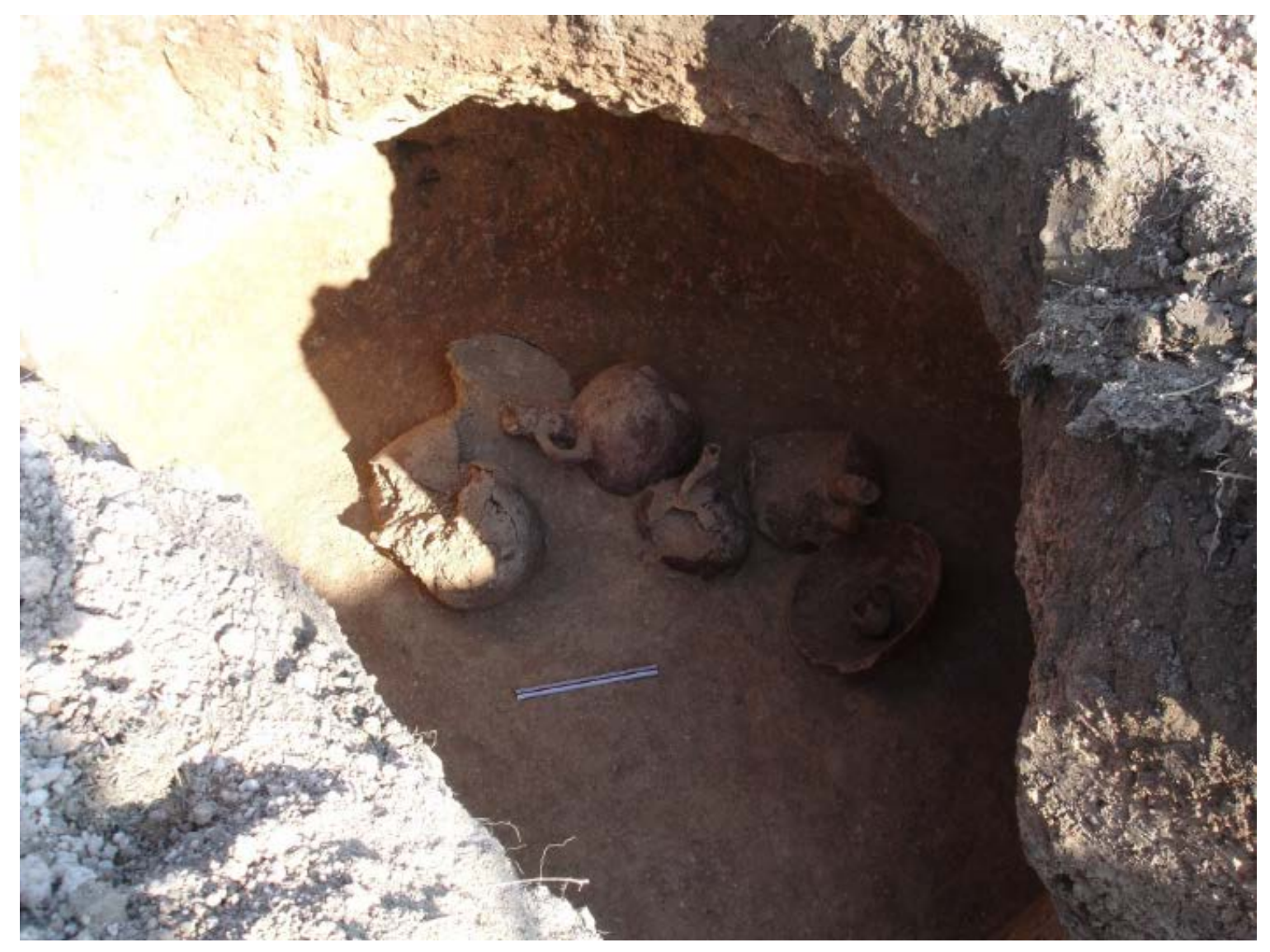

Figure 7. Early Bronze Age tomb, excavated by the Department of Antiquities, Republic of Cyprus (Image by Anna Satraki). 


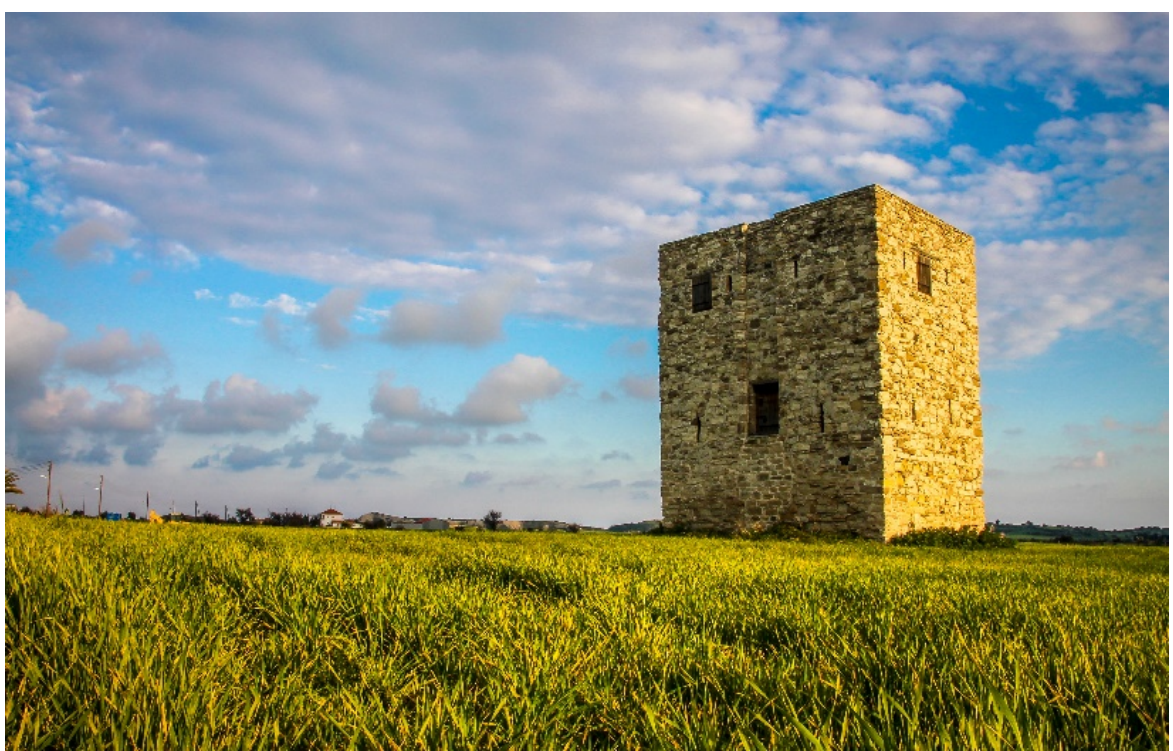

Figure 8. The Medieval tower of Alaminos at the locality of Kambos (Image by Adamos Papantoniou).

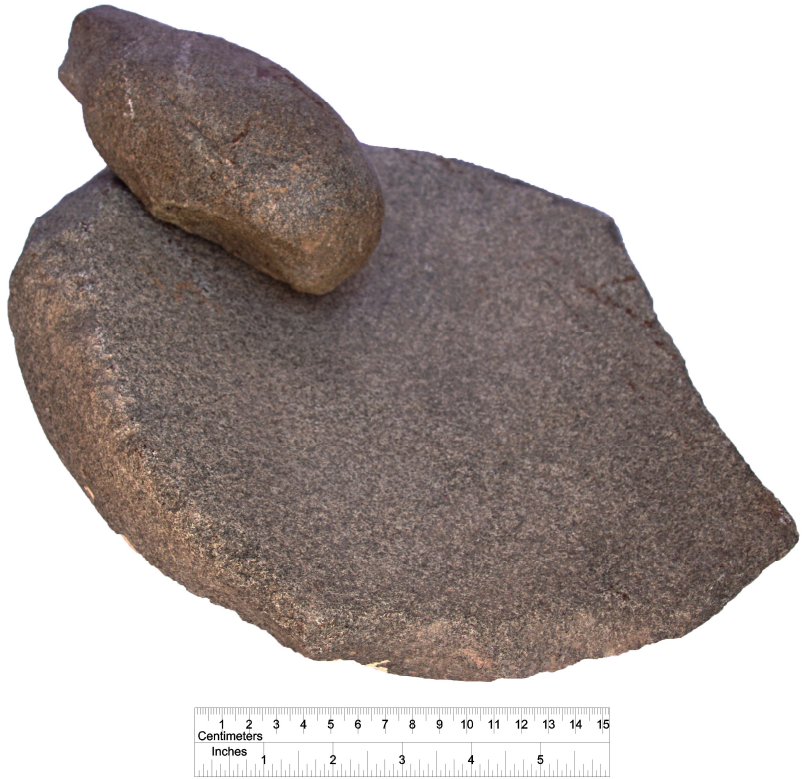

Figure 9. A millstone and grinding tool (Image by Athanasios K. Vionis).

Jennifer M. Webb and David Frankel have associated the appearance of Alaminos and similar sites on the south coast and in the central lowlands of the island with the establishment of settlements near copper ore deposits [25] (pp. 73-75). As we emphasised above, however, the good quality mines are located on the other side of the Troodos Mountain range. Our team has identified slag concentrations at the east of the survey area (Figure 10), although these come from a later, probably Hellenistic, Roman or mostly Late Antique date, based on the ceramic evidence from these transects. It is true that, so far, we have not recovered any signs for copper processing from the Early and Middle Bronze Age site of Alaminos. It is more likely that Alaminos-Kambos was a waypoint on a trade route along the south coast [23]. According to Webb and Frankel, Early Bronze Age communities on the south coast and in the central lowlands may have been subject to lower levels of social pressure than those in the (nowadays occupied by Turkish military forces) northern region of the island. For example, funerary practices and architecture, as in the cases identified by our team and the Department of Antiquities in the Xeros River valley, show relative simplicity and uniformity in comparison with evidence from the north part of the island [25] (pp. 73-75). Tombs on the south coast and the central lowlands are either 
relatively simple small chamber tombs or pit graves; dromoi are rarely evident and appear to have been intended simply to provide access to the chambers rather than a space for performance as in the case of the north coast. In addition, these communities living in the south coast and the central lowlands were probably largely self-sufficient in comparison to the north of the island, where they seem to have had intensive external contact ([26] cf. [27]).

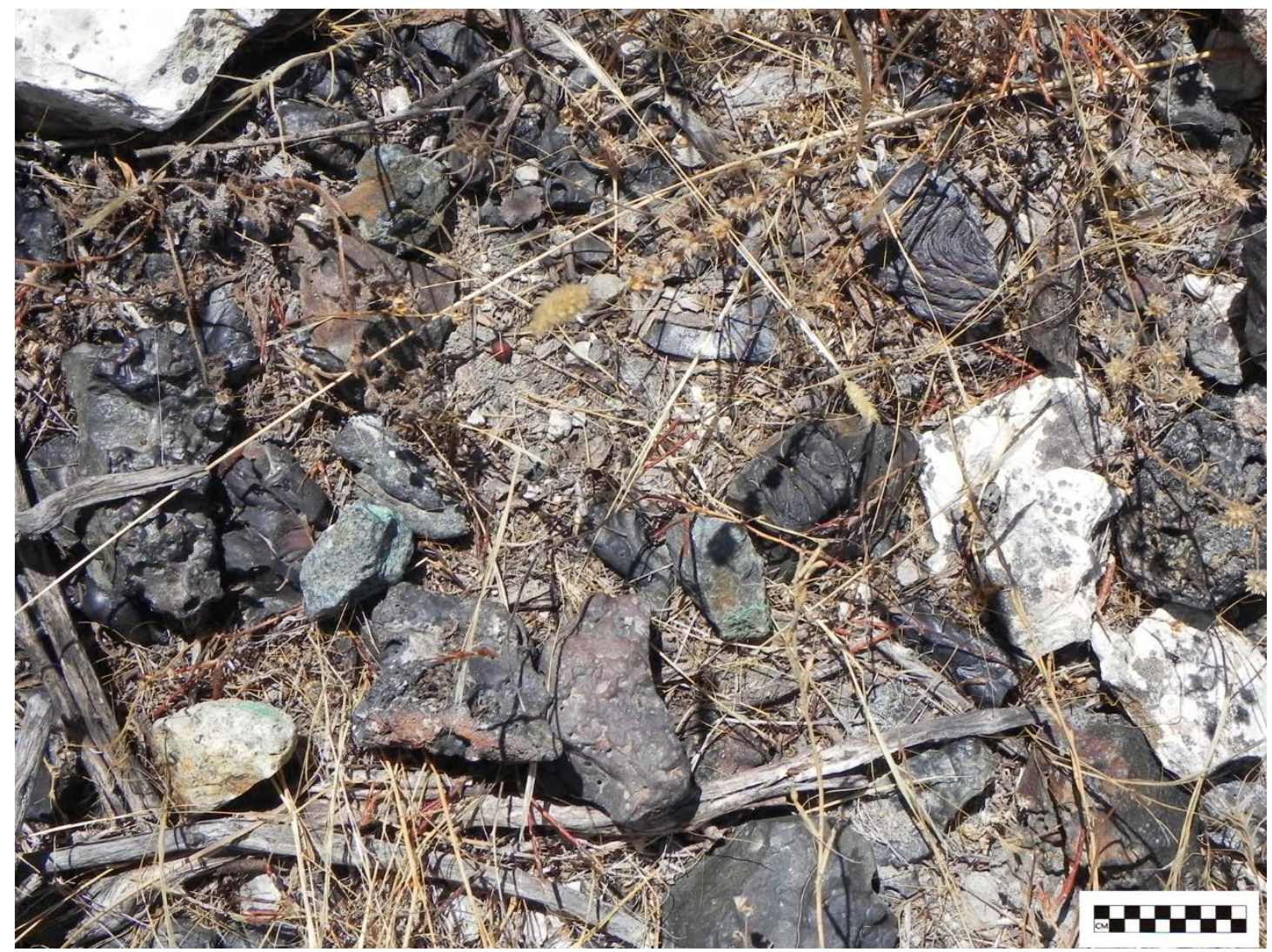

Figure 10. Copper slag concentrations to the east of our survey area (Image by Giorgos Papantoniou).

We hope that the future gridding of the site will further clarify the picture at regional scale. As suggested by the surface pottery recovered, the site of Alaminos-Kambos was established in the Early Bronze Age and continued to exist well into the Middle Bronze Age. Its size and population, however, cannot be safely estimated for any of the two periods due to the similar technological and other characteristics of the pottery and the lack of diagnostic sherds that can be safely attributed to non-generic Red Polished and other Bronze Age wares (see similar remarks in [28] (p. 34, Figures 3 and 4)). There is some-even if limited-evidence (such as dental enamel hypoplasia present on the dentitions of some skeletons excavated in some burials in Psematismenos or Marki) to suggest that, during the course of the Early Bronze Age, some communities on the south coast went through physical stress [25] (p. 75). It is possible that communities living in the relatively well-watered coastal plain and in river valleys, like the case of Alaminos, were better off.

\subsection{Late Bronze Age}

In comparison with other surface surveys and excavations west and east of the Xeros valley, it seems that, based on the existing evidence, the Late Bronze Age (ca. 1650-1050 BC) material is very limited. We need to point out, however, that this ceramic material is still under study. While we may be able to identify patterns of continuity from the Middle to the Late Bronze Age in the future, based on what we have recognised so far as 'potential Late Bronze Age material', such a continuity cannot be expected to be a major one in this region. In addition, with reference to the site of Alaminos-Kambos, 
such 'rural' settlement sites on the island were usually abandoned before the beginning of or very early in the Late Bronze Age [20][29] (p. 204). Nonetheless, the classic adage 'absence of evidence is not evidence' is very relevant to this case. Should we consider the possibility that the rural communities of the Middle Bronze Age in the Xeros River valley were gradually abandoned, following the rise of the complex copper-and-trade economic pattern at the beginning of the following period, and that their populations were gradually absorbed by the primary centres of the coast in the west and the east of the Xeros River valley?

The Late Bronze Age of Cyprus has been characterised as the apogee of urbanisation in the second millennium BC [21] (pp. 149-186), [24] (pp. 305-308), [30-34]. Two important urban centres (for early urbanisation and problems around the terminology in the case of Cyprus, see [35] (pp. 6-10, with references) and [36] (with references)), Kalavasos-Agios Dimitrios and Maroni-Vournes lie west of our survey area [36-40]. Similarly, east of the Pouzis River (Figure 3), several Late Bronze Age sites have been identified [41] (pp. 397-400), [42]. As evidence from outside the Xeros River valley suggests, towards the end of Late Cypriot II (just before 1200 BC), a gradual (not necessarily total) abandonment of the south coast and the central lowland urban centres of the island took place, while people seem to have moved to coastal urban centres, such as Palaipaphos, Hala Sultan Tekke, and Kition [43,44]. The flourishing nature of Late Cypriot II settlements in the Vasilikos valley is evident, as illustrated by the Vasilikos Valley Project (Figure 11), for example, with the Kalavasos-Agios Dimitrios complex lying at its centre [45] (pp. 94-97) (in the context of the Vasilikos Valley Project survey, the term 'site' was used to designate a locality where artefacts indicate some sort of human activity during any or many periods, including settlements, burials, manufacturing, and agricultural processing. To avoid confusion, in Figure 11 we have retained the term 'site' as defined by the surveyors). Meanwhile, the later phase of the Late Bronze Age and the Early Iron Age are marked by abandonment, even though some Late Cypriot III and Cypro-Geometric sites have been identified [45] (pp. 97-99), [46]. After the demise of Kalavasos-Agios Dimitrios and Maroni-Vournes as urban centres, people seem to have moved gradually to urban centres on the coastline itself, while we attest no other urban centres in the broader region.

Based on survey evidence from throughout the island, we would argue here that human activity in the Late Bronze Age seems highly nucleated around urban centres. The published material evidence of the Late Bronze Age rural landscapes stands in contrast to the abundant evidence for Early and Middle Bronze Age agrarian economy [5] (p. 147). Thus, one may ask whether the rural countryside was devoid of human occupation, something which is not supported by recent studies, suggesting alternative ways of looking at the rural countryside in the Late Bronze Age [5,47]. While it is true that there was a nucleation of the population and a focus of interest on the primary centres situated along the coast, fieldwork and research activities alike have shown that the Late Bronze Age polities consisted of a solid network of site-hierarchy. The coastal urban centres are certainly much more visible as they accommodated monumental architecture. However, the aforementioned survey projects at Vasilikos and Maroni valleys, as well as excavation projects in the hinterland, such as Aredhiou-Voupes which corresponds to an agricultural village [47], and rescue excavations of Late Bronze Age tombs in the northeastern slopes of the Troodos (Mathiatis, Sia, Lythrodontas, which probably correspond to mining villages) [48-50] all show the existence of secondary special-function sites in the hinterland that were undoubtedly associated with other centres. Systematic survey in the Xeros has not identified so far any surface evidence that could be termed as a 'Late Cypriot site', even if a tertiary hamlet or farmstead. This minimal evidence for the Late Bronze Age (at present at least) may be accounted for by the fact that it was possibly not associated with a major urban centre, and it may suggest that potential settlement localities at a considerable distance from urban centres on the south coast remained unexploited in terms of permanent habitation. On the other hand, seasonality of activity in the region is certainly a question to consider more closely in the future. 


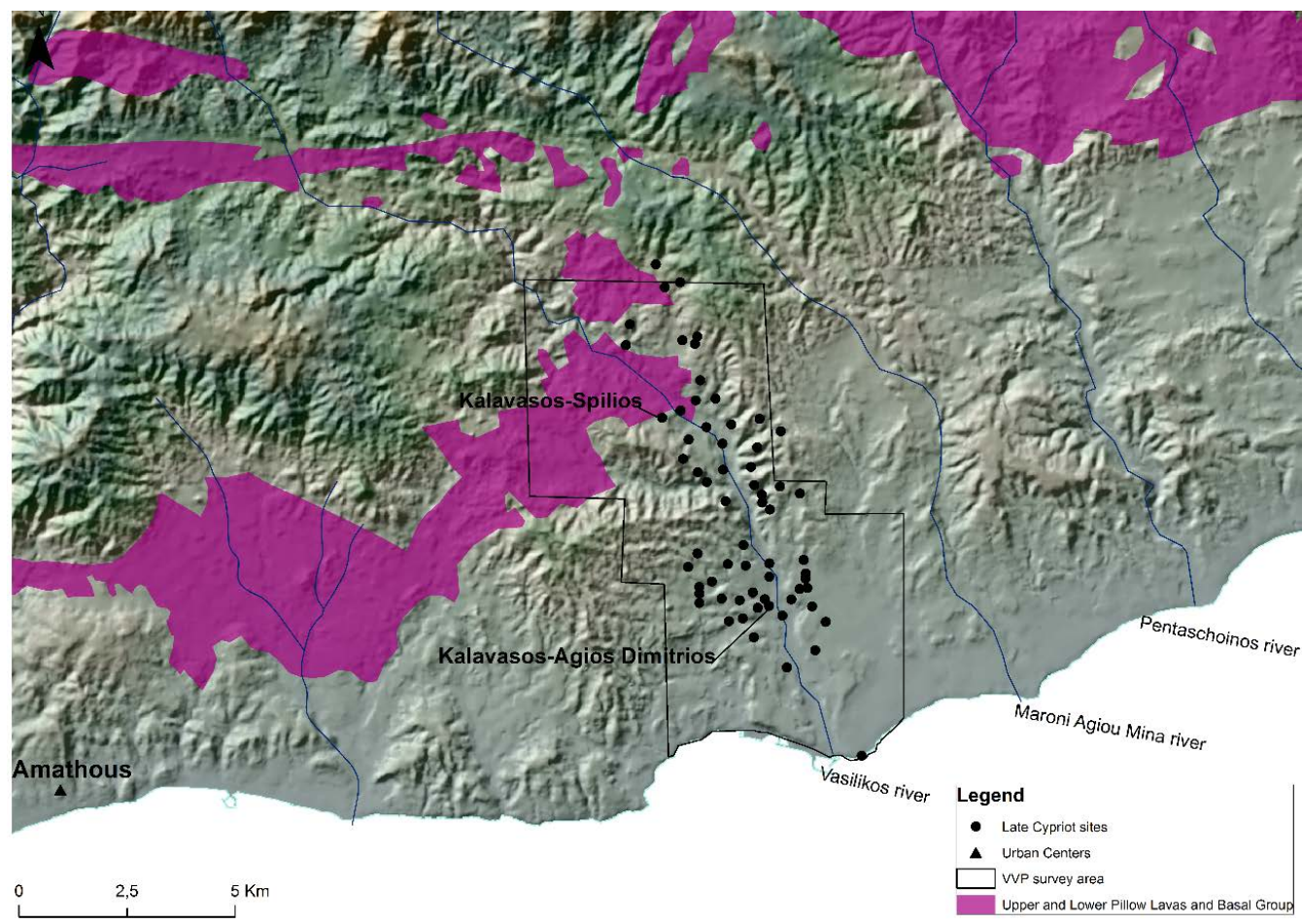

Figure 11. The Late Bronze Age centre of Kalavasos-Agios Dimitrios (and its settlement nucleation), west of our survey area. Digital data courtesy of the Geological Survey Department, Republic of Cyprus (Map by Niki Kyriakou).

\subsection{The Cypriot Iron Age}

Only a thin scatter of possible Cypro-Geometric (ca. 1050-750 BC) material has been recorded during the course of our field survey in the Xeros River valley (the ceramic material is under study). While this picture may in part be caused by issues of archaeological visibility and the lack of adequately excavated and published Cypro-Geometric strata, it accords with other survey evidence from the extra-urban territories of the Cypriot Iron Age polities (also referred to as Cypriot kingdoms or city-kingdoms) [45] (pp. 97-99), [46,51,52]. To this problem, we should add a long tradition of research focusing either on the problems around the establishment of the Cypriot city-kingdoms or on the later Cypro-Archaic period, with a poorer interest in understanding rural landscapes and the Cypro-Geometric period itself (cf. [5] (with references)). Because of the limited presence of identified Cypro-Geometric settlement strata generally in Cyprus, the study of the existing mortuary evidence has been the main route for exploring the social, political, and economic transitions and transformations that the island underwent from the Late Bronze Age to the Iron Age (for the most recent and coherent discussion on this issue, see [6]). It is generally accepted that the Early Iron Age is a period that comes after a general disorder and movements of people and ideas in the broader Mediterranean. This unsettling period was a time when negotiations of individual, societal, and political identities took place. In the course of Late Cypriot IIIB/Cypro-Geometric I (ca. 1125/1100-950 BC), a new political geography began to be established on the island [6].

As we already mentioned, in the Cypro-Archaic (ca. 750-480 BC) and Cypro-Classical (ca. 480-310 BC) periods, the Xeros River valley became a flourishing un-central landscape (or territory) at the intersection of various central places-i.e., the urban centres of Amathous, Idalion and Kition-all of which eventually functioned as seats of an Iron Age polity (Figure 12). The north sector of the valley preserves evidence for the existence of small hamlets and farmsteads, around a larger centre of some 10 ha at the location of Kophinou-Panagia (Figure 13). Twelve looted tombs on the south edge of the same site may also date to this phase according to surface ceramic evidence (Figure 14), even if the site and this type of tomb continue to be in use later in the Hellenistic and Roman 
periods (Figures 15 and 16). Such 'satellite' settlements in 'un-central' landscapes, such as the Xeros valley, were economically associated with (and probably under the political control of) a polity, most probably Amathous.

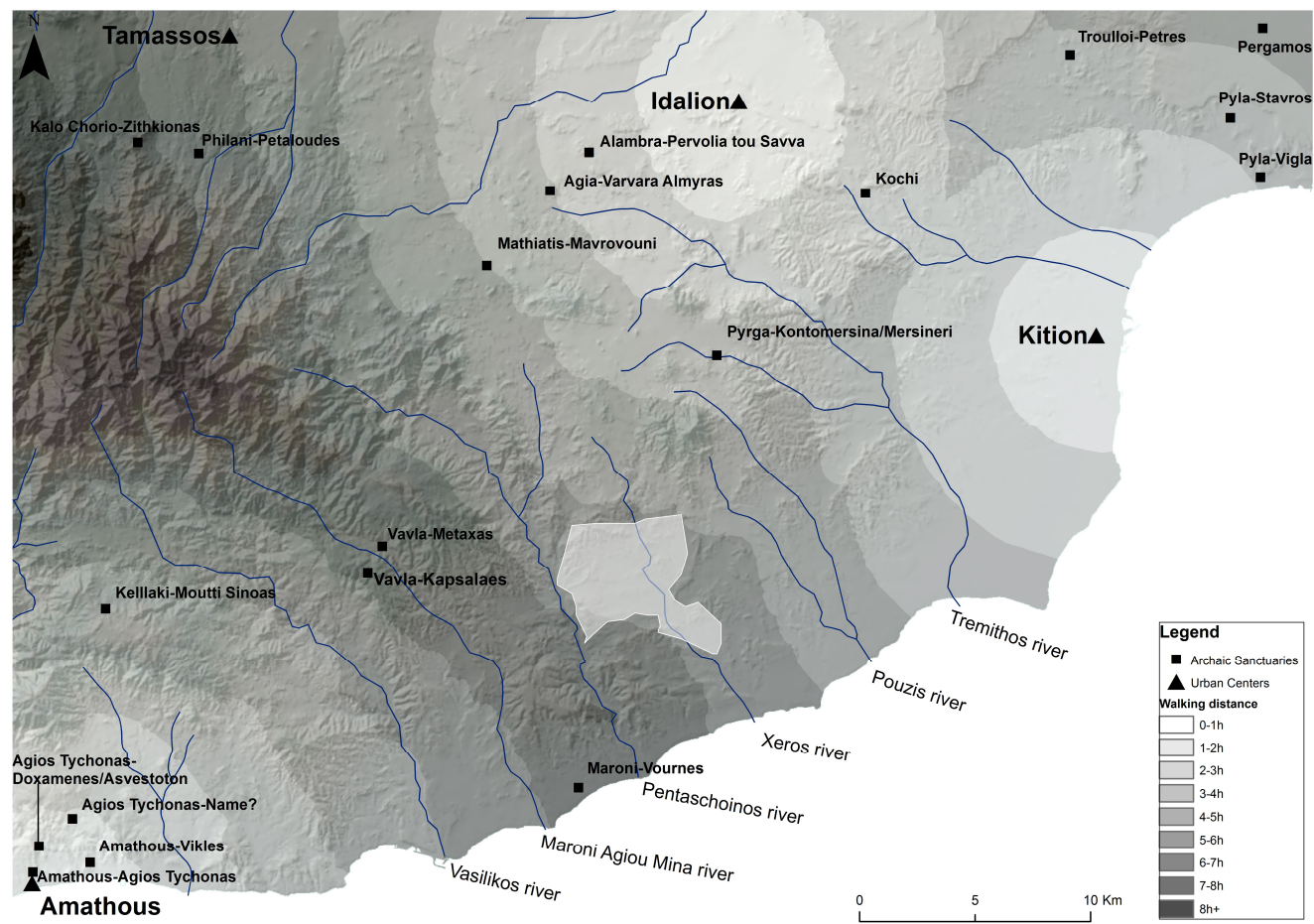

Figure 12. In the Cypro-Archaic period, the Xeros River valley became a flourishing territory at the intersection of various Iron Age polities. Digital data courtesy of the Geological Survey Department, Republic of Cyprus (Map by Niki Kyriakou).

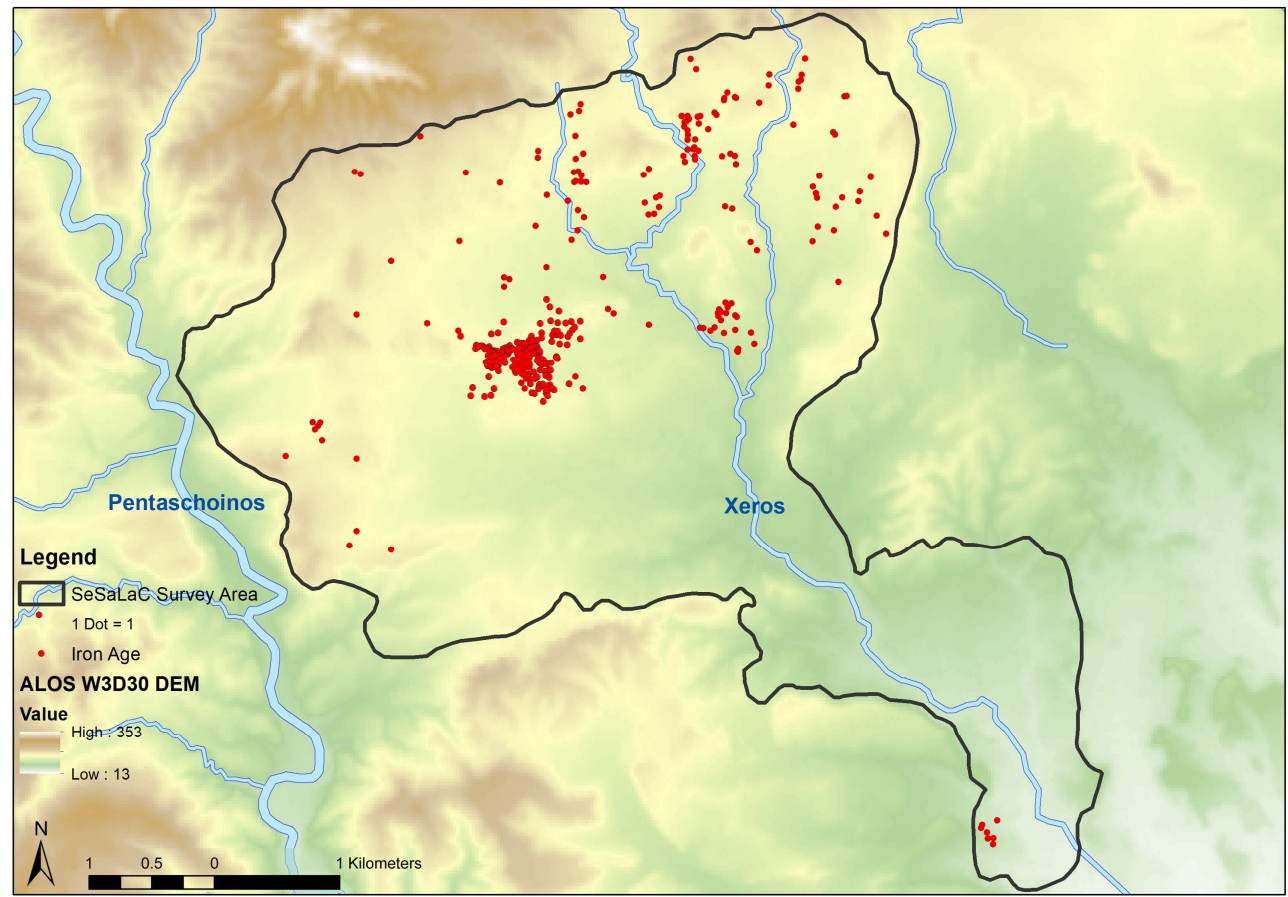

Figure 13. Cypro-Archaic and Cypro-Classical pottery distribution. ALOS DEM are in metres. Digital data courtesy of the Geological Survey Department, Republic of Cyprus (Map by Charalambos Paraskeva). 

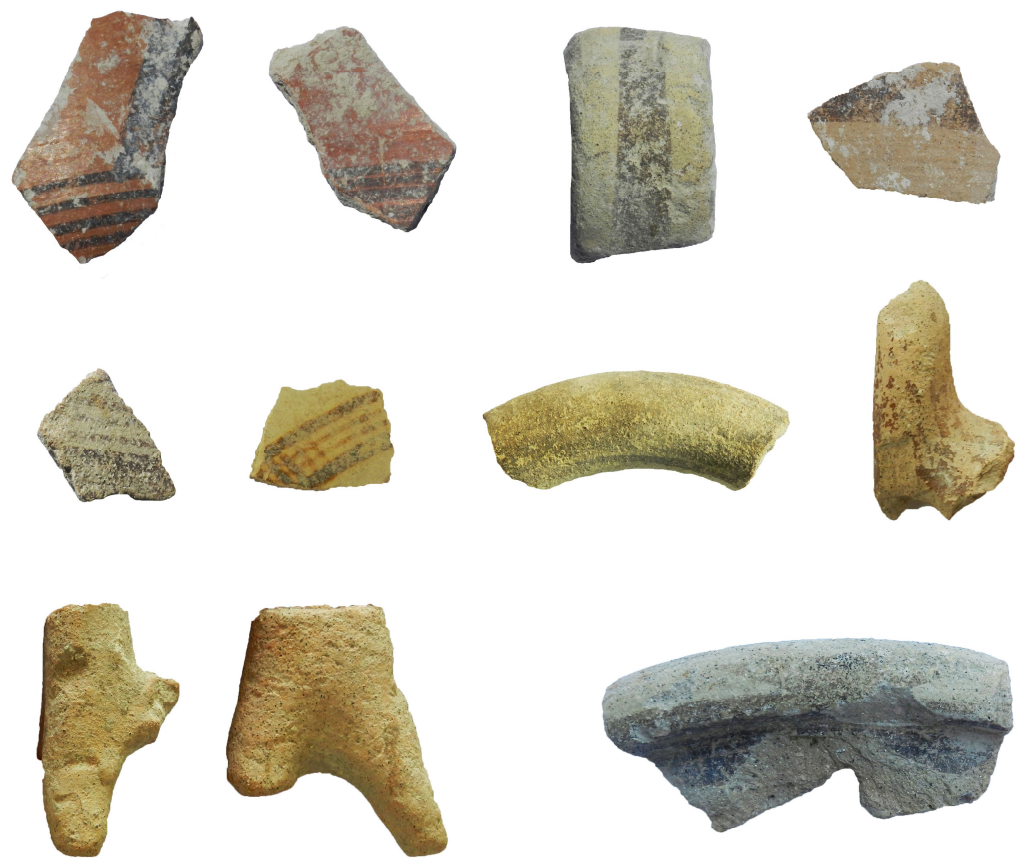

Figure 14. Iron Age pottery and terracotta figurines from the site of Kophinou-Panagia in the Xeros River valley (Image by Athanasios K. Vionis).

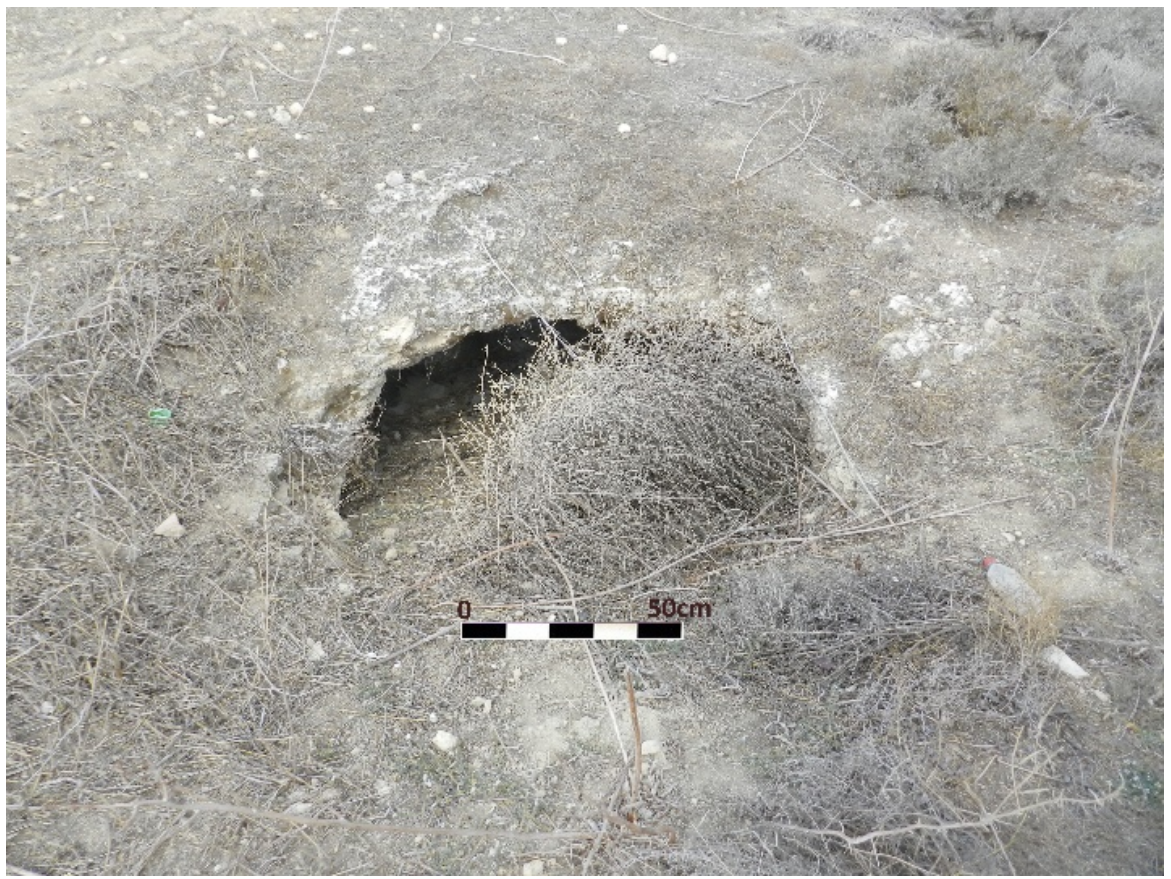

Figure 15. A looted rock-cut tomb at the site of Kophinou-Panagia, most probably of the Iron Age (Image by Athanasios K. Vionis).

Future ceramic studies need to clarify the percentage of Cypro-Archaic and Cypro-Classical pottery in order to identify whether the Cypro-Classical settlement density, similarly to the Vasilikos valley for example [45] (pp. 99-103), [53] (pp. 129-158), is significantly reduced when compared to the Cypro-Archaic. Anna Georgiadou is currently working on altering the picture of the presence of Classical pottery in the settlements of the south coast [54]. Still, based on the existing published evidence, we have to note that during the Cypro-Classical period, an apparent reduction in settlement 
activity is attested in the Vasilikos valley again. According to the surveyors, the valley seems to have reverted to a backwater of little significance [45] (p. 102), but this reduction remains unexplained. We anticipate that the archaeological surveys in the neighbouring Maroni River valley and in the Xeros, and perhaps a future field project in the region of Choirokoitia, will provide alternative explanations, especially as this minimal evidence in the Vasilikos valley is in complete contrast to the urban centre of Amathous, which has provided abundant evidence of political and economic power during the Cypro-Classical period [55] (pp. 208-290, with references).

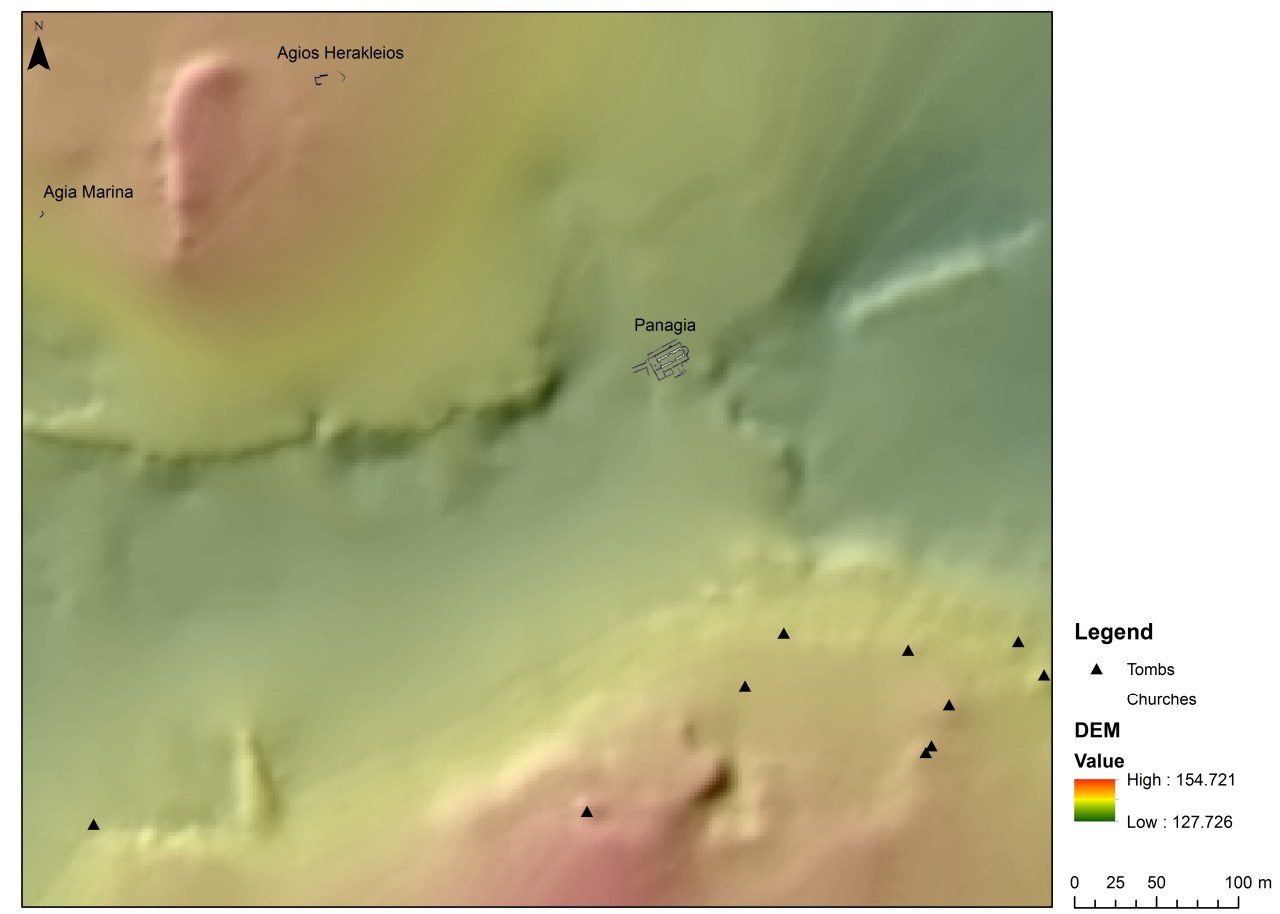

Figure 16. Group of rock-cut tombs at the south edge of Kophinou-Panagia (Map by Niki Kyriakou).

Our surface survey throws further light on much-debated issues in the current scholarship relating to the Cypriot city-kingdom polities as 'central places' and their economic 'un-central' territories. Our research builds significantly on earlier studies of Cypriot regionalism and its association with an economic model of successful micro-regions $[4,6,23,56,57]$. The lower foothills of the Troodos Mountains from north of Amathous to the Kalavasos region are rich in copper ore deposits. The area between the Vasilikos and Maroni valleys seems to have belonged (at least most of the time) to the territory (or sphere of interest) of Amathous, based on the geographic, numismatic, and archaeological evidence [4] (p. 550, with references). The eastern area of the Troodos, from the upper Pentaschoinos River and north of Stavrovouni Mountain to Idalion, is also rich in copper deposits and appears to form a different geographic unit. Copper slag has been found at Mathiatis, Lythrodontas, Agia Varvara-Almyras, and Sia [57] (pp. 53-56), [58]. At Agia Varvara-Almyras, in particular, the entire process of copper extraction and smelting has been identified [59].

In the context of the Unlocking Sacred Landscapes of Cyprus (UnSaLa-CY) project, we have argued on several occasions that extra-urban sanctuaries may have played a significant role in the territorialisation (a process related to the control of the extra-urban space) of the various city-kingdoms [7] ([4] with earlier references), [60]. The sanctuary sites of Pyrga, Mathiatis, and Lythrodontas, should be associated with the destiny of the polities of Idalion and Kition. While Antoine Hermary, based on the natural landscape and later textual evidence, has assigned the area east of Stavrovouni Mountain-just northeast of our survey area-(Figure 3) down to the sea, east of Mazotos, to the territory of Amathous [61] (pp. 25-26), Terence B. Mitford (again on the basis of later textual evidence) [62] (p. 1339) allocated the area lying east of the Pentaschoinos River to Kition. 
Elsewhere, the French team excavating Amathous, also suggests that Pentaschoinos was the natural boundary for the Amathousian territory [63] (p. 8). In this context, as mentioned above, we should note that Kition probably became the seat of a city-kingdom only in the Cypro-Classical period [6] (pp. 33-34, with references). The texts cited by Hermary, including the Roman geographer Claudius Ptolemy and later Byzantine and Medieval sources, should be considered with caution as there are several problems behind their interpretation: some of these texts refer to Mount Olympus (identified with Stavrovouni) as attached to the city of Amathous, and the villages of Kophinou and Alaminos as attached to Limassol [61] (p. 26). In addition (even if this is again not unproblematic given that several pre-Kitchener maps of Cyprus are extremely inaccurate with several name corruptions), it is interesting to note that a map [61] (plate I) dating to 1718 and copying earlier maps showing the Roman military road network, refers to Amathusia Regio and to Amathi Regnum (Figure 17) [64] (p. 22); the cartographer carefully represents landmarks, including Mount Olympus and the boundaries of the Amathusi Regnum: these boundaries are clearly placed east of the Xeros River valley and Mount Olympus.

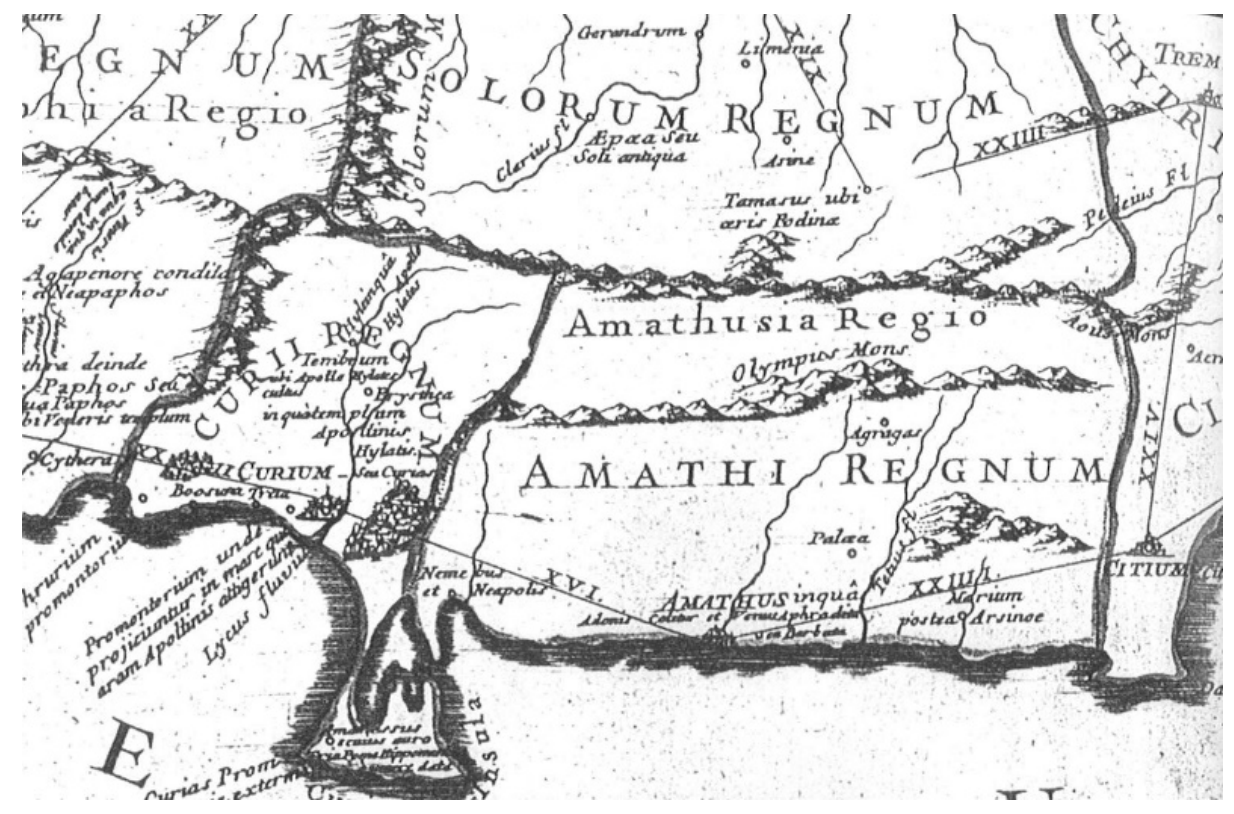

Figure 17. A map dating to 1718 but copying earlier maps showing the Roman military road network, referring to Amathusia Regio and to Amathi Regnum ([64] (p. 22, figure 16)).

As already mentioned above, the Xeros River valley is clearly located in a frontier zone between the polities of Amathous, Idalion, and Kition. Current trends in social anthropology and archaeology do not foster models that present human societies as stiff, static, and mechanistic; through the concept of materiality they refer to the ongoing dynamics of human and thing relations, avoiding conclusions about the history of a region or people by applying spatial distribution and culture-historical approaches of different territorially fixed cultures [65]. SeSaLaC explores alternatives to culture-historical approaches in an attempt to shift the focus from object-centre to actor-centred perspectives. We acknowledge that analytical networks are often traced on the basis of a shared material culture (same pottery shapes, styles, clays or raw materials), but this is not an unproblematic method. A preliminary study of the Cypro-Archaic and Cypro-Classical surface ceramics has demonstrated that about $95 \%$ of the sampled material is made of fabrics, shapes, and styles that are similar to the pottery found at the very centre of Amathous (personal communication with A. Georgiadou, Iron Age pottery specialist, who undertook a preliminary study of the material, 23 September 2018). Most of the recovered pottery demonstrates the stylistic and technical attributes of the Amathousian style; in general, the Amathousian clay products, either terracotta figurines or pottery, display the same fabrics characterised by the presence of numerous tiny black inclusions of coastal sand from the (present-day) Limassol district [46] (pp. 95-96, with references). 
The petrographic study of ceramic samples is still in progress, with the aim to explore and evaluate further the origin and distribution of the Cypro-Archaic and Cypro-Classical pottery based on macroscopic observation. Chemical analysis of surface pottery from different sites in the Xeros valley, using portable X-ray fluorescence spectroscopy (pXRF), however, reveals that all the Iron Age material from our survey area forms a homogeneous group, especially when compared with the Late Roman pottery (Figure 18). This suggests that the clay sources used in the Iron Age were very different from those exploited during Late Roman times; it should be noted here that a Late Roman pottery workshop site in our survey area in Xeros was discovered in the 2017 field-season (see below). Furthermore, as seen in Figure 18, the Iron Age decorated wares, which clearly correspond to the Amathous regional style, fall within the same physicochemical category as the undecorated wares, indicating that they were produced in workshops using the same clay sources. The Principal Component Analysis (PCA) of two groups of samples, i.e., our Iron Age surface pottery and contemporary ceramic samples from the palatial context of Amathous, groups the large majority of the fragments together (Figure 19). While these remain preliminary results, future work comparing the Xeros Iron Age pottery macroscopically and chemically with more samples from Amathous, Kition, and Idalion will further clarify the picture.

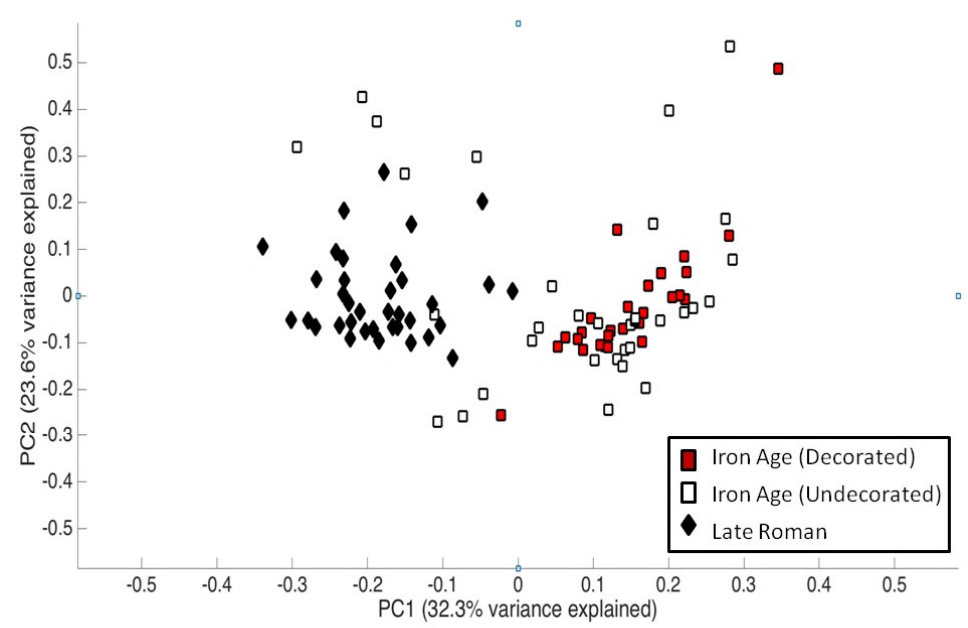

Figure 18. The pXRF and statistical analysis of Iron Age and Late Antique pottery from the Xeros River valley (Principal Component Analysis by Andreas Charalambous).

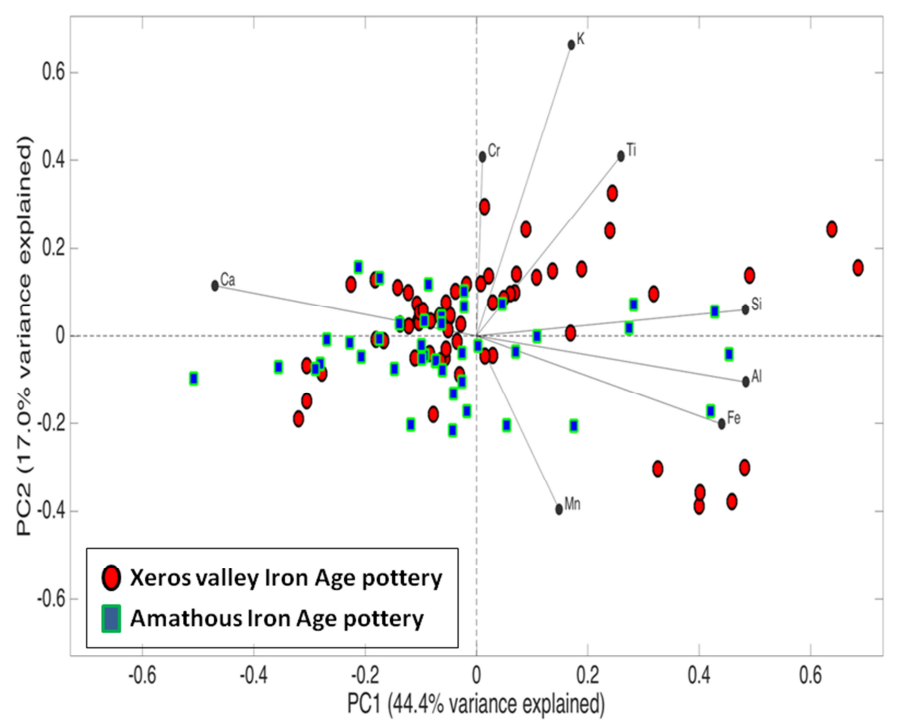

Figure 19. The $\mathrm{pXRF}$ and statistical analysis comparing the Xeros River valley Iron Age pottery with pottery from the palace of Amathous (Principal Component Analysis by Andreas Charalambous). 
The preliminary pottery analyses (macroscopic and chemical) by the SeSaLaC team may reinforce Hermary's interpretation, suggesting that during the Cypro-Archaic and Cypro-Classical periods, the Amathousian territory may have extended well beyond the Pentaschoinos River towards Stavrovouni. The archaeological data may thus be in conflict with David W. Rupp's 1987 problematic Thiessen polygons [66], reproduced in the following years by many scholars of Cypriot archaeology (cf. [4] for a critique), and which associate the Xeros valley with the territories of Idalion and Kition. On the other hand, we accept that regional variation is a common phenomenon in the production of objects, but its presence should not necessarily be associated with political or even clear-cut cultural boundaries. Artistic and pottery production in Iron Age Cyprus seems to have been organised in highly localised workshops. Localisation in production, however, is largely determined by geography and geology. We should probably primarily associate the regional styles with material availability, technological considerations, and workshops' spheres of influence rather than with clear-cut political entities or domination [55] (p. 106).

The cultural unity of the city-kingdoms in Cyprus seems to rely on a multi-layered composition of regional variability created by inter-regional influences, while the stylistic (at least) comparison with the Amathousian production has to be viewed vis-à-vis to other material culture indicators, epigraphic sources, and topographical features discussed above, to further clarify the picture [4]. Georgiadou, looking closely at the ceramic fabrics, shapes and decorative techniques from the Vasilikos River valley, suggests that the homogeneous pottery from the valley, in comparison to that from the centre of Amathous, illustrates a case for the definition of these workshops, including "aspects of controlled and centralised organisation of the pottery production directed from the capital" [46] (p. 105). Should we refer to pottery production or the simple trade (of pottery or via pottery) directed from the capital? Based on the above discussion and the existing evidence, we cannot yet be conclusive on the above, or on the mode of circulation of Iron Age pottery in the Amathousian territory (and Cyprus in general), but we hope that the SeSaLaC Xeros River valley project will shed more light on this complex methodological issue.

The extensive survey we undertook on the hills surrounding the Xeros valley has produced no evidence for the existence of a Cypro-Archaic or Cypro-Classical sanctuary. Considering the long distance and the density of sanctuary sites elsewhere on the island, it remains a paradox that no definite sanctuary sites appear in the bibliography concerning the broader region between Maroni and ancient Kition [60] (p. 35, figures 1 and 2). We have identified a small number of terracotta figurines and a limestone statuette (that we provisionally dated to the sixth or fifth century BC) commonly found also in sanctuaries (Figure 20) (cf. [67] (p. 265, no. 539)) but, in any case, the concentration of evidence does not allow us to suggest the presence of a possible sanctuary [55] (pp. 373-375). It is probable that these figurines were originally deposited in a tomb or even a household, while (in rare instances when we have a context) such a limestone statuette has also been found in a tomb in the very centre of Amathous [68] (p. 19, no. 6). In addition, more male statuettes of this type have also been found in Amathous, one at the locality of Vikles and the other in the context of the Amathousian palace within the metallurgical workshops which were also related with a 'palatial sanctuary' [69] (p. 128, nos. 845, 847). While this may be coincidental, it is important to note that our own statuette was found in the same plots as the aforementioned slag concentration.

While we do not consider elevation as a defining characteristic of frontier sanctuaries, when we look for frontier sanctuaries outside the Mesaoria plain, elevation may have indeed played a significant role. In sanctuaries like Vavla-Kapsalaes, Ipsonas-Agios Sylas, and Kato Platres-Kambos tou Koulourou, just to mention a few, where evidence for the segmentation of space, consumption of food and drink (suggesting their role as a meeting space), large-scale storage and display, and the disposal of votive images (probably related to the elite or the royal) has been found, we have enough evidence to suggest that these places may have functioned as a frontier sanctuary [4] (p. 570) (cf. [70]). All these sanctuaries are located on elevated ridges. While our ongoing extensive surface survey on the cliffs surrounding the Xeros valley has not identified an ancient sanctuary so far, tradition (since 
the Middle Ages) implies that the Stavrovouni Mountain, the highest mountain in the area, may have once hosted a sanctuary [71] (p. 441), [72] (p. 428), [73], [74] (pp. 13-17). There is limited evidence for a possible sanctuary (or more) in the broader Stavrovouni region, but the orientation of these sites (although orientation alone is not a safe criterion to allocate a sanctuary to a territory [4]) towards Pyrga [58], along with the aforementioned geographical description, may relate these sites primarily with Idalion or Kition.

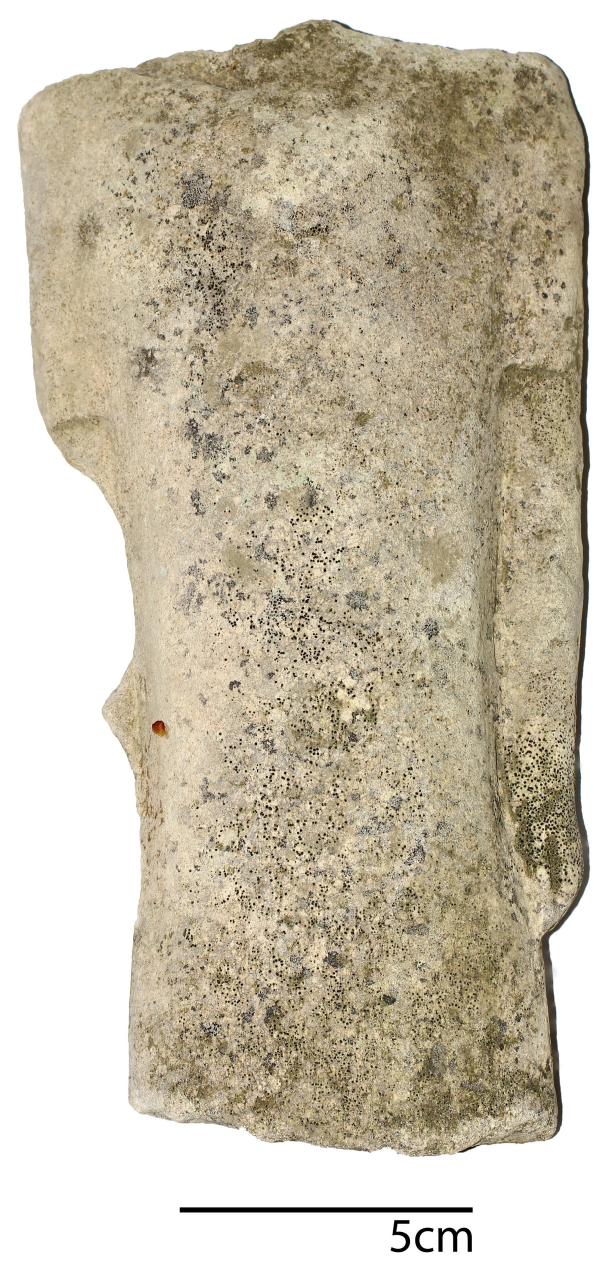

Figure 20. A limestone statuette found in the Xeros River valley (Image by Charalambos Paraskeva).

\subsection{Hellenistic and Roman Periods}

Settlement activity, represented by a hamlet-site at the location of Kophinou-Panagia together with a number of satellite farms, continues throughout Hellenistic (ca. 310-30 BC) and Roman (ca. $30 \mathrm{BC}-330 \mathrm{AD}$ ) times, despite the fact that the archaeological material is visibly reduced (Figure 21). However, this image may alter (even if not significantly considering our preliminary examination of the material) as the material from the southern part of the valley remains to be dated. The transformation of Hellenistic political topographies and the passing of Cyprus from segmented to unitary, colonial administration under a foreign general (the Ptolemaic strategos) brought a marked urban and extra-urban change $[55,75]$. The gravitation of people towards coastal cities was of greater historical significance. Several archaeological surveys on the island have noted a busy Hellenistic and early Roman countryside, followed by a general contraction from the second through the fourth centuries AD [7] (with references) [76] (with references). Evidence of Severan prosperity, which is often taken to represent the apogee of Roman Cyprus, is overwhelmingly urban and may have come about at the expense of the countryside [76]. Although we also recorded a lower density of archaeological 
material dated to the Hellenistic and Roman periods in the Xeros valley, we cannot observe any major transformations in land use patterns.

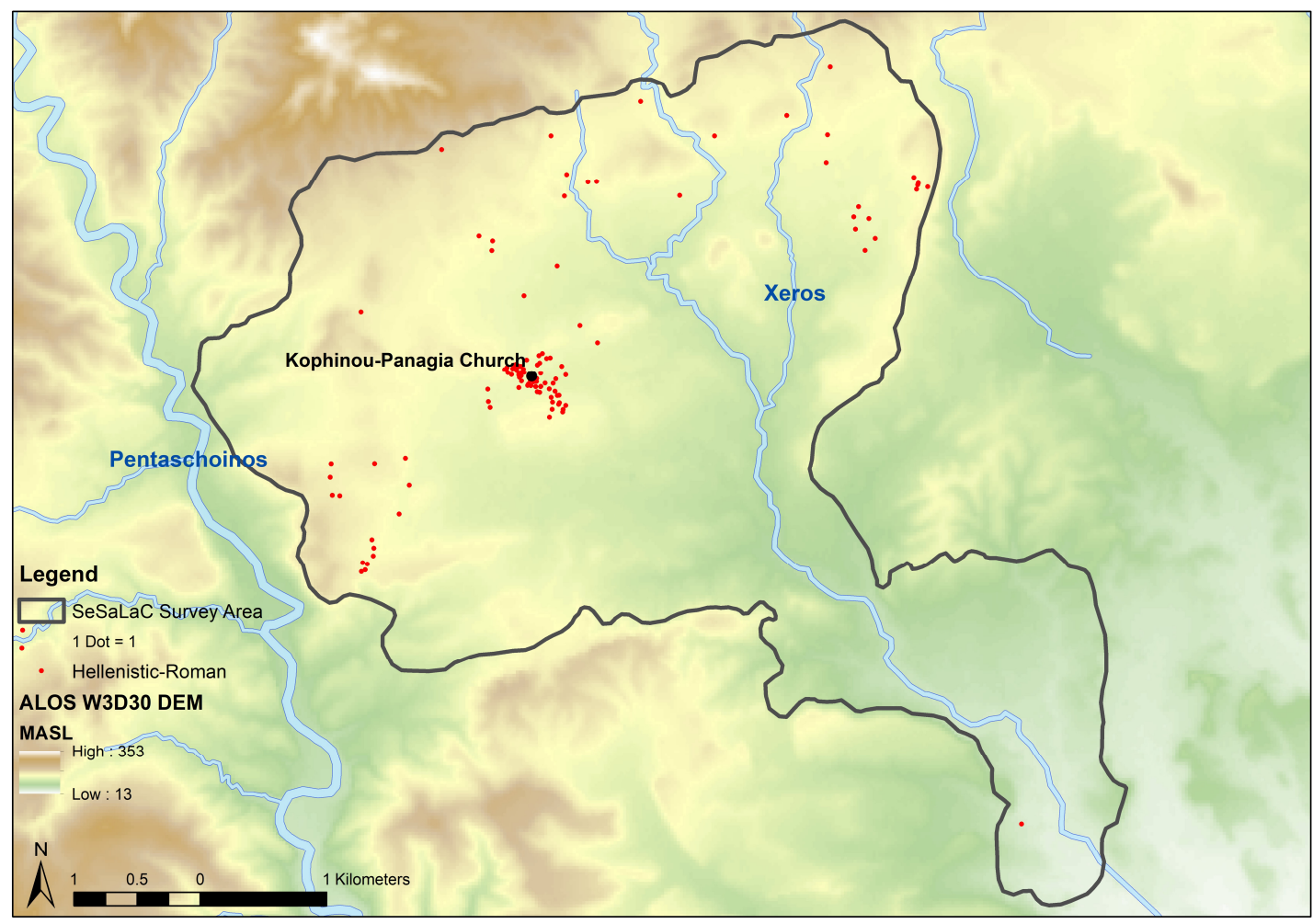

Figure 21. Hellenistic and Roman pottery distribution. ALOS DEM are in metres. Digital data courtesy of the Geological Survey Department, Republic of Cyprus (Map by Charalambos Paraskeva).

\subsection{Late Antiquity}

By the middle fourth century AD, the social transformations taking place throughout the Eastern Mediterranean led to gradual changes in the urban centres and in the countryside. Settlements and new cult sites dating to the fifth century AD, like the basilicas at Karpasia, Lapithos, Tremithous, and Yialousa, document both the expansion of rural settlements and the successful Christianisation of the countryside [76]. At the very centre of our research area, excavations revealed the foundations of a three-aisled basilica of the sixth or early seventh century AD, upon the central aisle of which the eleventh-century AD church of Panagia was erected. The distribution of Late Antique pottery at the site gives the impression of a thriving rural establishment of some 13 ha in size (Figure 22). Overall, Late Antiquity (ca. 330-650 AD) occupies the greater percentage of the total dated pottery (to this moment) in the Xeros valley assemblage (Figure 23).

It is also striking that three quarters of the Kophinou ceramic assemblage represent tiles, transport jars and large pithoi (such large and heavy vessels, when broken, produce a smaller number of fragments when compared to the fragile fine tableware), made of similar-looking clays, and intended for everyday household use (Figure 24). This does not come as a surprise; as also noted above, we have identified a large Late Antique ceramic workshop $2 \mathrm{~km}$ northeast of Kophinou and next to the river (Figure 2), through an overwhelming concentration of wasters, overfired pottery and kiln furniture (Figure 25). The workshop, in proximity to the river, the Roman road-network of the island, and the coast, produced almost every class of domestic ceramics, from roof-tiles and water pipes, to pithoi, smaller storage and transport jars, jugs and basins, as evidenced by the wide range of forms represented in the assemblage of overfired and misshaped vessels. This is a unique find for the period in Cypriot archaeology. 


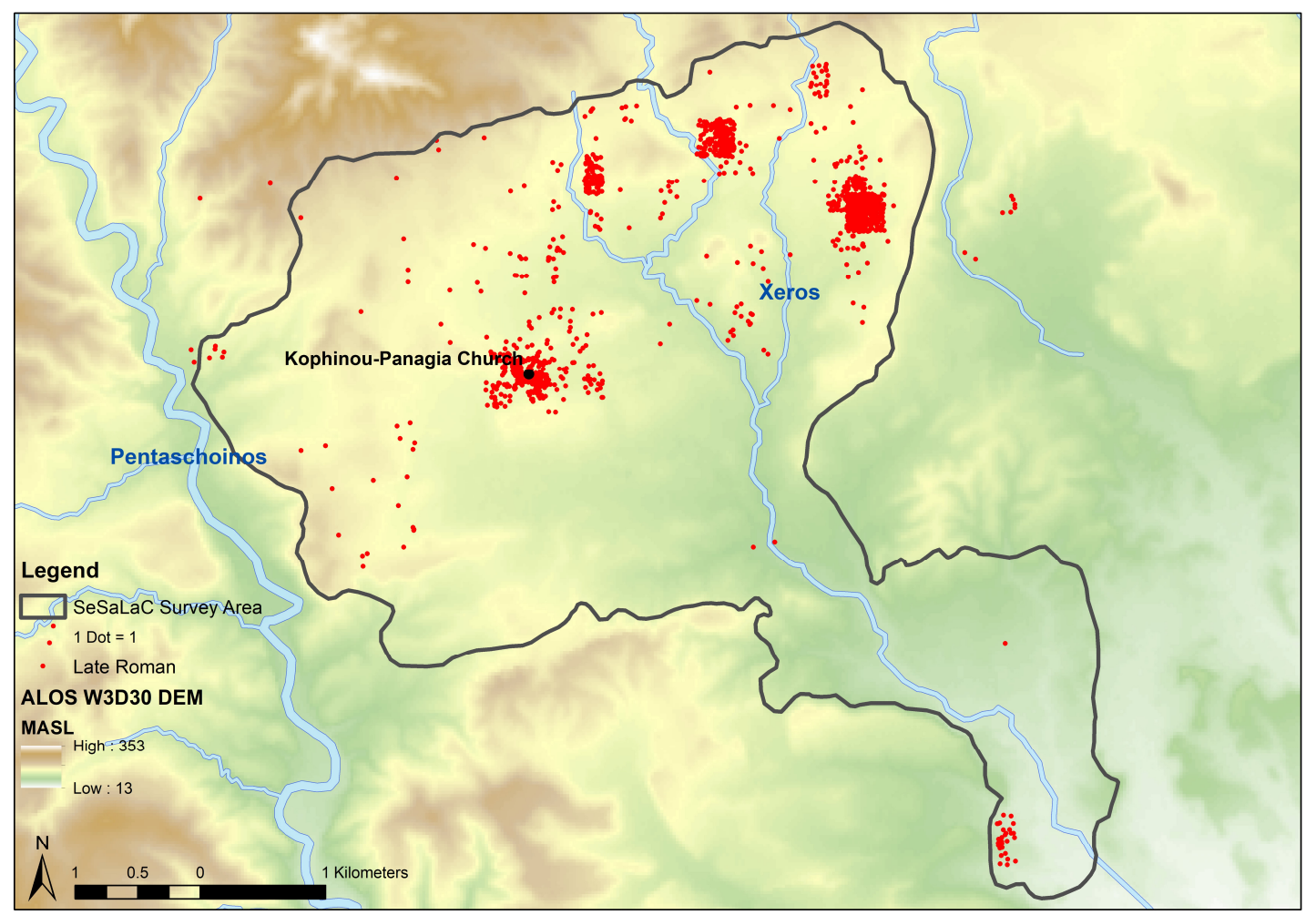

Figure 22. Late Antique (Late Roman) pottery distribution. Digital data courtesy of the Geological Survey Department, Republic of Cyprus (Map by Charalambos Paraskeva).

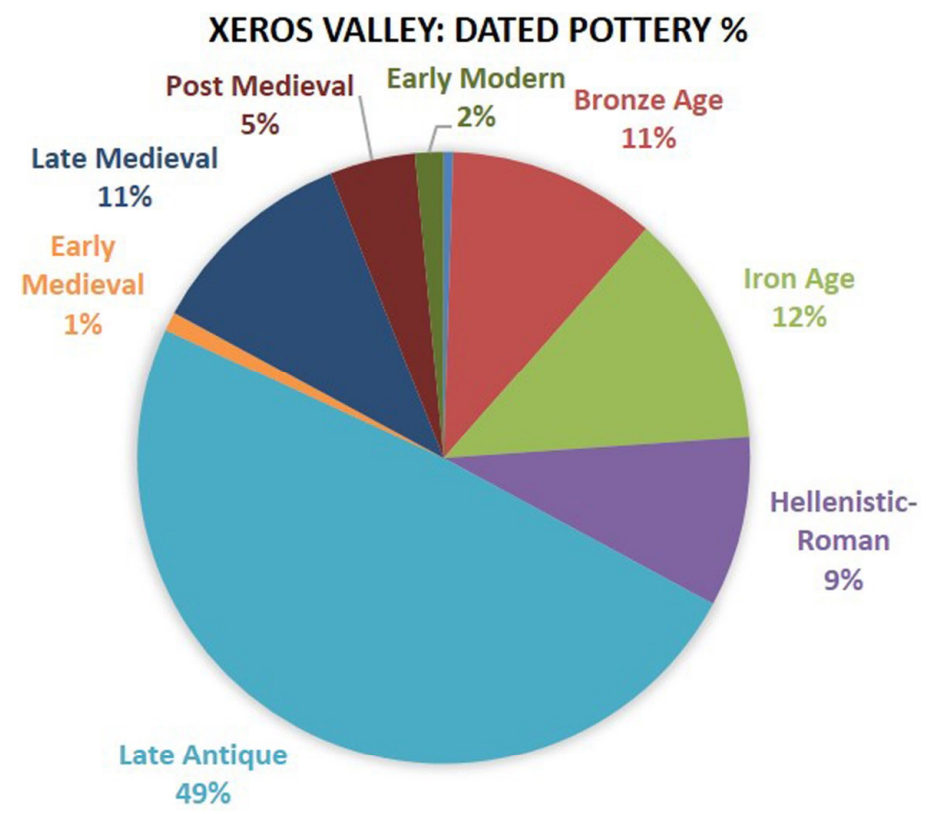

Figure 23. The percentages of dated pottery from sites in the Xeros River valley (Graph by Athanasios K. Vionis).

The ceramic evidence, the presence of monuments of Christian worship, topographic parameters, an extensive surrounding agricultural territory and comparative evidence from other excavated and surveyed sites suggest that in Late Antiquity the site of Kophinou played a central role within its 'settlement chamber', overlapping with our survey area. The extent of the site suggests that the settlement should have accommodated approximately 250 families during its maximum size in the 
sixth and seventh centuries AD. The excavated basilica functioned as the focal point of the settlement, standing at its approximate centre, and dominating its immediate environs.

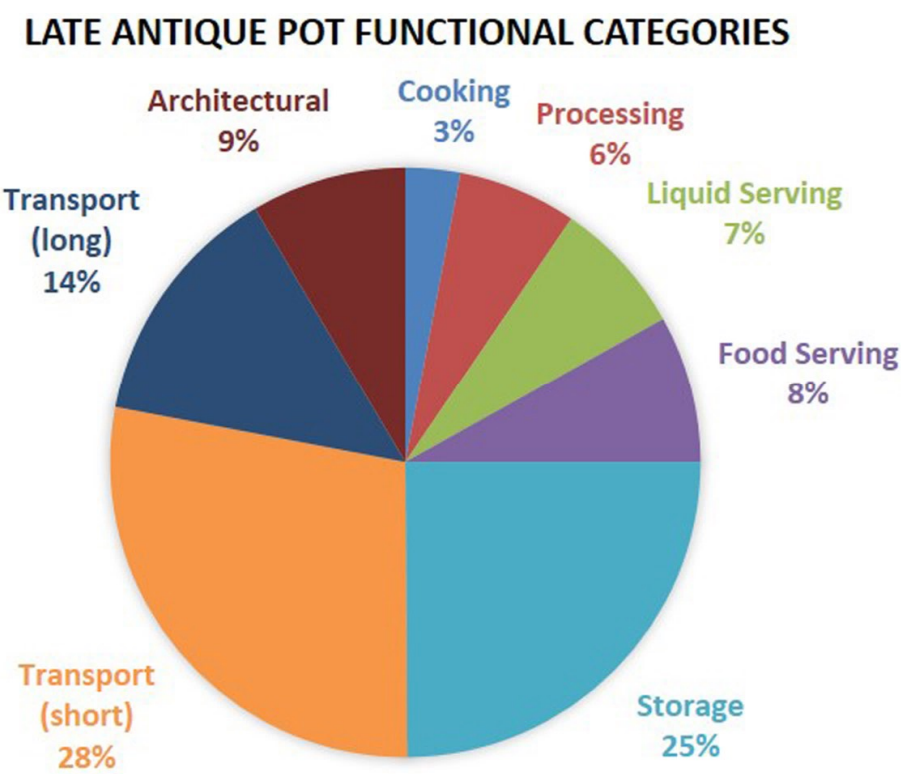

Figure 24. The functional categories of Late Antique (Late Roman) pottery from sites in the Xeros River valley (Graph by Athanasios K. Vionis).

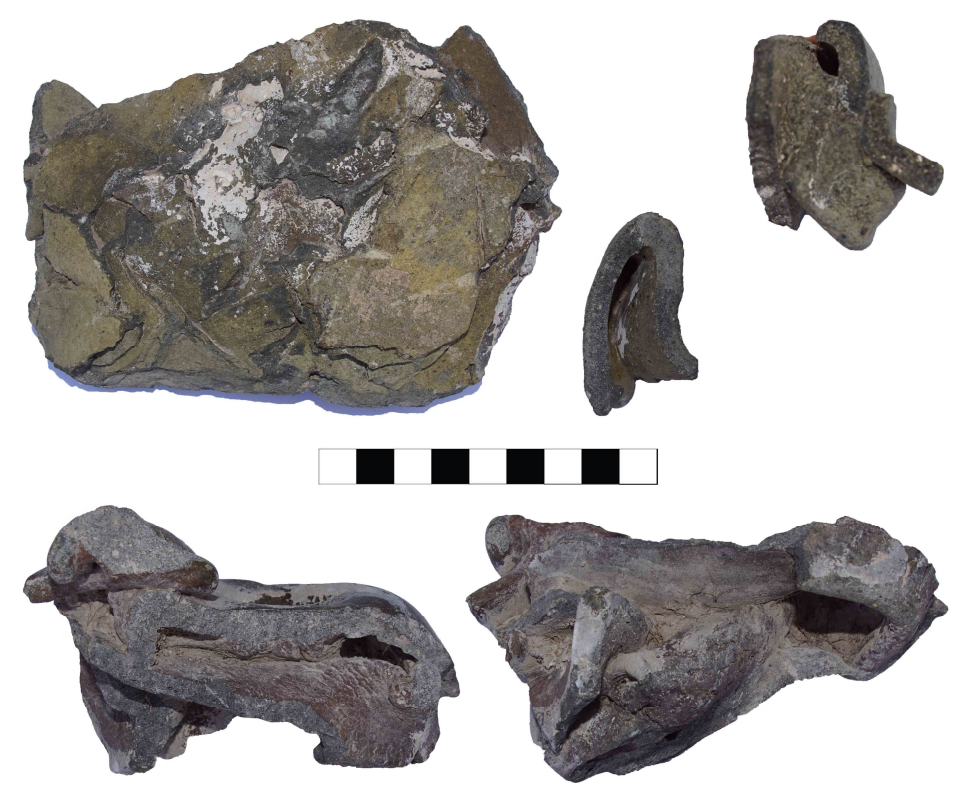

Figure 25. Kiln furniture and wasters from the Late Antique (Late Roman) pottery workshop in the Xeros River valley (Image by Athanasios K. Vionis).

As we have extensively argued elsewhere $[7,77,78]$, considering central place theory, Kophinou functioned as a second-rank settlement, and as the main habitation site of the micro-region of the Xeros River valley in Late Antiquity. Such secondary settlements in the countryside had a major role to play as local centres, that is, as important loci within the territory of their 'settlement chamber', acquiring an important role in agricultural production, processing, and distribution of goods. Part of an unusual type (in the case of Cyprus at least) (cf. $[79,80]$ ) of a probable olive-press system may date to Late Antiquity (Figure 26). GIS analyses, such as Viewshed and Cost-Surface, support the idea of the centrality of the largest of settlement-sites in the region, at the centre of the settlement-chamber of the Xeros River valley (Figures 27 and 28). Thus, Kophinou could be defined here as an 'agro-town', 
fitting into an adaptive agricultural and economic system, subject to the pressure of international markets and changing balances between arable and pastoral lands. This new interpretation finds fertile ground in the full landscapes of Late Antique Cyprus and other places in the Eastern Mediterranean, within a 'global' superstructure as the Eastern Roman Empire [81].

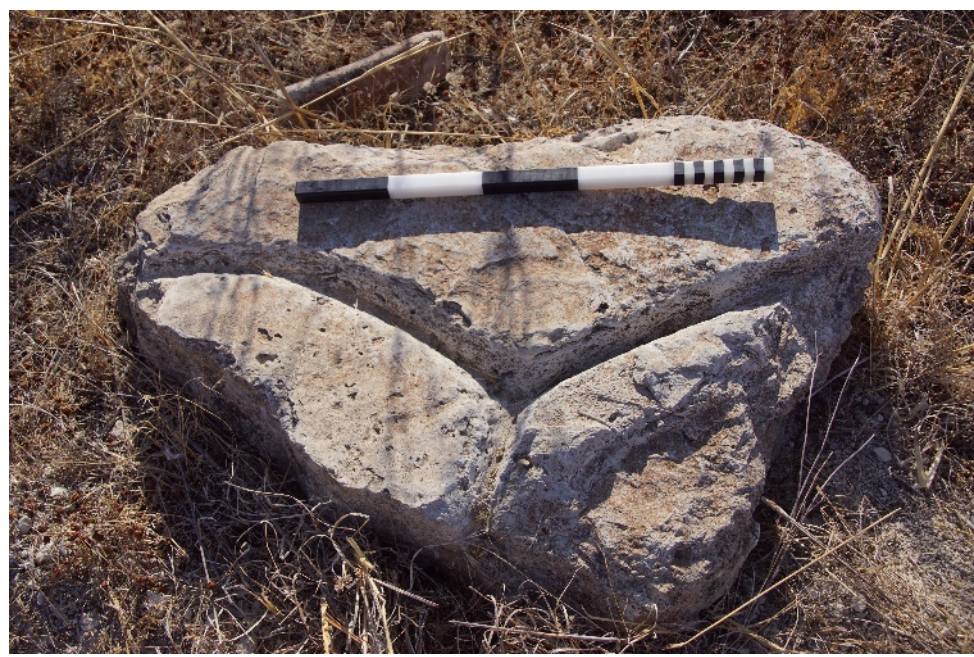

Figure 26. A probable olive press found in a Late Antique hamlet-site in the Xeros River valley (Image by Athanasios K. Vionis).

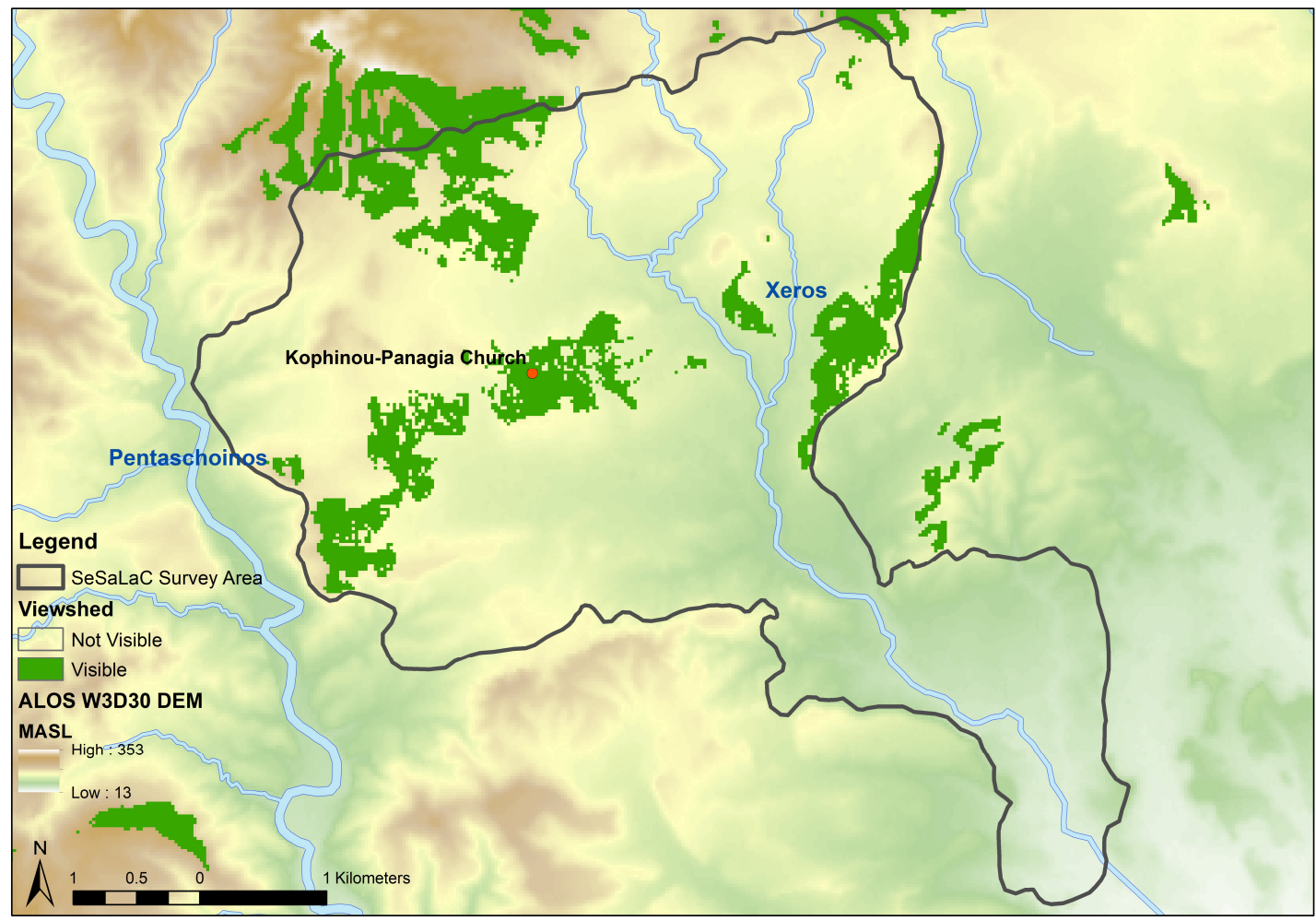

Figure 27. Viewshed Analysis from the Late Antique site of Kophinou-Panagia at the centre of the Xeros River valley. To create the Viewshed (at $1.8 \mathrm{~m}$ above ground), certain factors (such as the potential existence of tall trees and high buildings) cannot be taken into account due to the lack of evidence for pre-modern vegetation and land-use. Digital data courtesy of the Geological Survey Department, Republic of Cyprus (GIS analysis by Charalambos Paraskeva). 


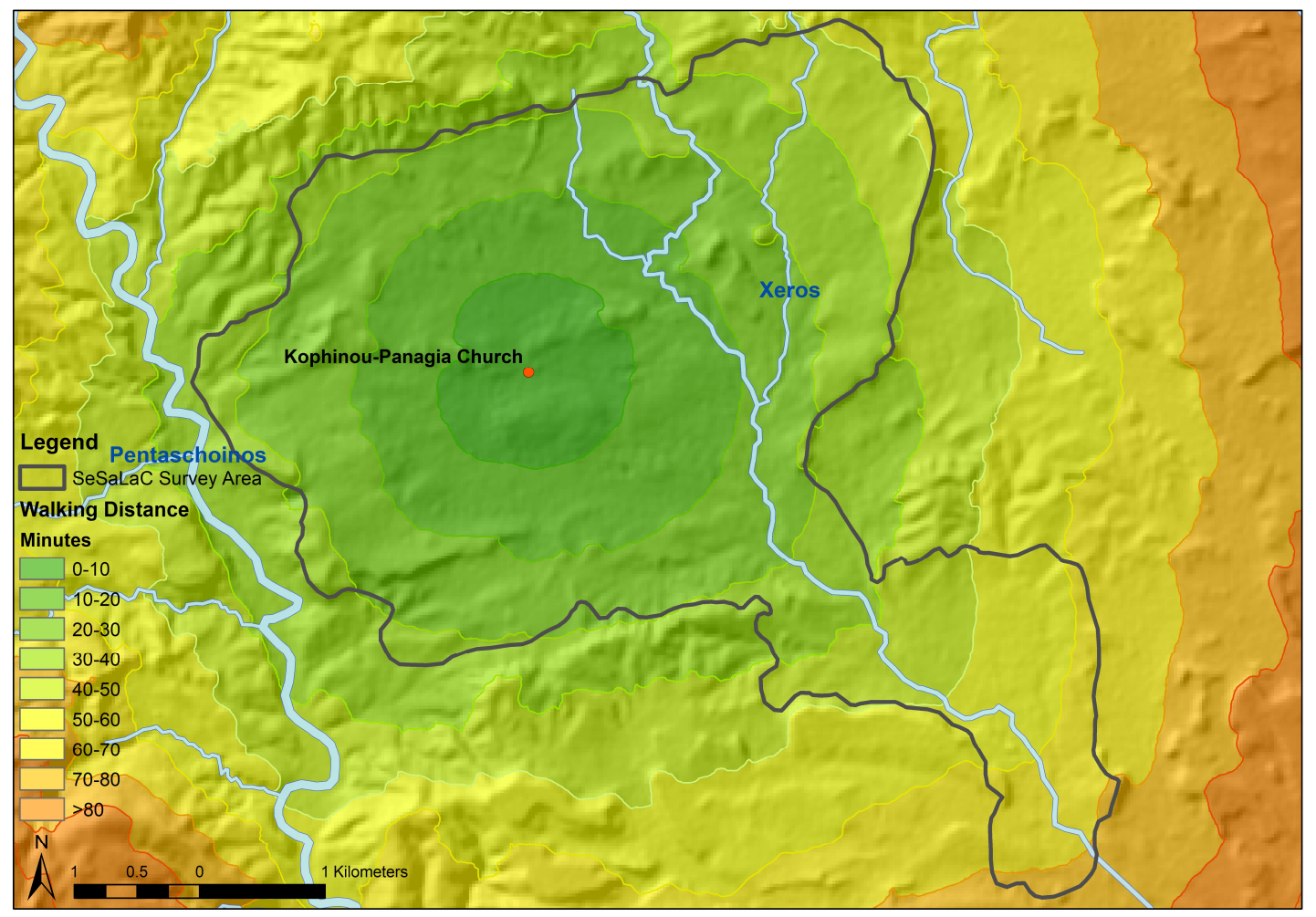

Figure 28. Cost Surface Analysis from the Late Antique site of Kophinou-Panagia at the centre of the Xeros River valley. Digital data courtesy of the Geological Survey Department, Republic of Cyprus (GIS analysis by Charalambos Paraskeva).

\section{Conclusions}

Concluding, we hope that we have managed to manifest how surface survey and landscape archaeology can provide a fresh perspective and a powerful investigative tool to address research questions related to the conscious and the unconscious shaping of the land and the processes of organising space, involving interaction between the physical environment and human presence in the longue durée. The changing social and material worlds of a large population living in the countryside has received less attention, but regional surface surveys can illustrate that the centrality of a place can be seen as the result of inter-reliant socio-political processes relating to natural environment, on different spatial scales, ranging from the local to the supra-regional [82]. The consideration of political geography and political economies play a significant role in any discussion concerning the development of settlement patterns. Regional surface surveys offer bottom-up perspectives on these political economies, offering at the same time diachronic configurations of patterns of habitation.

Un-central landscapes such as the Xeros River valley, surrounding the coastal and inland towns, conditioned the increasing wealth and power of central authorities (such as the Iron Age polities or the Late Antique bishoprics) through the management of agro-pastoral goods and metal resources (cf. $[6,7,83])$. These un-central landscapes, whose settlement network and land-use practices are increasingly recorded through a number of recent and ongoing surface survey projects, provide a rich source of material for investigating political economies, settlement organisation, and social transformations diachronically (cf. [84]).

Waterways had a prominent role in shaping the settled landscapes of southeast Cyprus diachronically [9]. Examining the Xeros River valley from the perspective of political economy and natural resources, we attempted to show how an 'un-central landscape' may have functioned as a place of economic or ideological centrality. The Xeros River clearly acted as an economic asset in making this 'un-central' landscape central, diachronically. Water procurement and management seem to have determined the clear tendency for settlement along the main Xeros River and the small valleys 
formed by its streams from prehistory to Late Antiquity, always at a safe distance from the water to avoid the risk of flooding (cf. [85]).

Water and rivers are understood to have specific powers and agencies related both to life and destruction $[11,86]$. The management of riverine water, such as the cases of Ottoman watermills both in the Xeros and the nearby Pentaschoinos valleys for example (Figure 29), should be scaled at the level of its associated communities and environments. Rivers, incorporated into social and ecological developments, were particularly vibrant elements in periods of economic crisis, stability and growth.

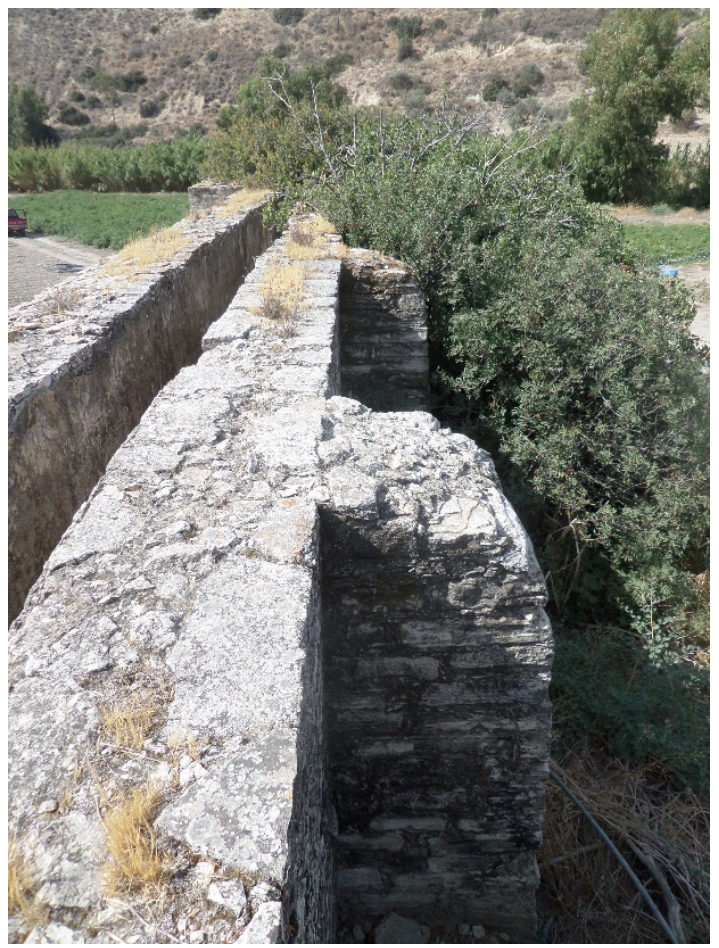

Figure 29. A Late Ottoman watermill outside the present-day village of Alaminos in the Xeros River valley (Image by Athanasios K. Vionis).

Author Contributions: G.P. and A.K.V. contributed equally to the writing of the article. This is the result of an ongoing research collaboration, long discussion and exchange of expertise between the two authors.

Funding: Data collection and analysis was funded by the University of Cyprus, the Irish Research Council (IRC), the Dumbarton Oaks Centre for Byzantine Studies, and the Research Training Group 1878: Archaeology of Pre-Modern Economies, a joint research program of the Universities of Bonn and Cologne (funded by the Deutschen Forschungsgemeinschaft-DFG), to which we are grateful. The project has also recently secured funding from the Cyprus Research Promotion Foundation (RESTART 2016-2020, Excellence Hubs, EXCELLENCE/1216/0362).

Acknowledgments: Some of the digital data used for the production of maps in this article are courtesy of the Department of Geological Survey, the Department of Land and Surveys, and the Department of Agriculture of the Republic of Cyprus, while others have been collected by SeSaLaC. Colleagues and students collaborating with our project have contributed immensely in data recording and collection (Doria Nicolaou, Charalambos Paraskeva, Agata Dobosz, Chrystalla Loizou, Niki Kyriakou, Vasilis Trigkas, Katerina Ragkou, Pantelitsa Mylona, Andreas Charalambous). We are particularly grateful to Charalambos Paraskeva and Anna Georgiadou for commenting on the parts of this article concerning the prehistoric and Iron Age pottery, and to Jennifer M. Webb, Artemis Georgiou, Georgia Marina Andreou, Vasiliki Kassianidou and Antoine Hermary for sharing their expertise on specific points in this article. We also wish to extend our gratitude to the three anonymous reviewers for their constructive comments and suggestions. Finally, we are very thankful to the Department of Antiquities of the Republic of Cyprus, especially to Anna Satraki, Eleni Procopiou and the staff of the Larnaka District Museum for facilitating SeSaLaC's research in the Xeros River valley, and to Eleftherios Charalambous for supporting us in many different ways.

Conflicts of Interest: The authors declare no conflict of interest. 


\section{References}

1. Foxhall, L. The dependent tenant: Land leasing and labour in Italy and Greece. J. Rom. Stud. 1990, 80, 97-114. [CrossRef]

2. Pettegrew, D. Chasing the classical farmstead: Assessing the formation and signature of rural settlement in Greek landscape archaeology. J. Mediterr. Archaeol. 2001, 14, 189-209. [CrossRef]

3. Bintiliff, J.L. Problems of chronology and function in survey assemblages: The 1999 Hidden Landscape debate reviewed. In Hidden Landscapes of Mediterranean Europe: Cultural and Methodological Biases in Preand Protohistoric Landscape Studies: Proceedings of the International Meeting Siena, Italy, 25-27 May 2007; British Archaeological Reports, International Series 2320; van Leusen, M., Pizziolo, G., Sarti, L., Eds.; Archaeopress: Oxford, UK, 2011; pp. xv-xix, ISBN 978-1407309033.

4. Papantoniou, G.; Kyriakou, N. Sacred landscapes and the territoriality of Iron Age Cypriot polities: The applicability of GIS. Am. J. Archaeol. 2018, 122, 541-577. [CrossRef]

5. Andreou, G.M. Understanding the urban landscape of Late Bronze Age Cyprus: A diachronic perspective from the Vasilikos Valley. J. Mediterr. Archaeol. 2016, 29, 143-172. [CrossRef]

6. Iacovou, M. Historically elusive and internally fragile island polities: The intricacies of Cyprus's political geography in the Iron Age. Bull. Am. Sch. Orient. Res. 2013, 370, 15-47. [CrossRef]

7. Papantoniou, G.; Vionis, A.K. Landscape archaeology and sacred space in the eastern Mediterranean: A glimpse from Cyprus. Land 2017, 6, 40. [CrossRef]

8. Karyda, E. Sailing from coast to coast: Cabotage on the Cypriot south coast. In Approaching Cyprus, Proceedings of the Post-Graduate Conference of Cypriot Archaeology (PoCA), Norwich, UK, 1-3 November 2013; Maguire, R., Chick, J., Eds.; Cambridge Scholars Publishing: Cambridge, UK, 2016; pp. 78-95, ISBN 978-1-4438-9477-7.

9. Brown, M. Waterways and the political geography of south-east Cyprus in the second millennium BC. Annu. Br. Sch. Athens 2013, 108, 121-136. [CrossRef]

10. Devillers, B. Holocene Morphogenesis and Anthropisation of a Semi-Arid Watershed, Gialias River, Cyprus; British Archaeological Reports, International Series 1775; Archaeopress: Oxford, UK, 2008; ISBN 978-1-4073-0263-8.

11. Steel, L. Watery entanglements in the Cypriot hinterland. Land 2018, 7, 104. [CrossRef]

12. Knapp, A.B. Seafaring and Seafarers in the Bronze Age Eastern Mediterranean; Sidestone Press: Leiden, The Netherlands, 2018; ISBN 9789088905544.

13. Andreou, G. Monitoring the impact of coastal erosion on archaeological sites: The Cyprus ancient shoreline Project. Antiquity 2018, 92, 361. [CrossRef]

14. Andreou, G.M.; Georgiou, A.; Urban, T.; Fisher, K.D.; Manning, S.D.; Sewell, D.A. Reconsidering coastal archaeological sites in Late Bronze Age Cyprus: Tochni-Lakkia and the south-central coastscape. Bull. Am. Sch. Orient. Res. 2018, in press.

15. Hadjikoumis, A. Ethnoarchaeology as a means of improving integration: An ethnozooarchaeological study from Cyprus and its contribution to the integration of zooarchaeology with archaeobotany and other lines of archaeological evidence. In Environmental Archaeology. Interdisciplinary Contributions to Archaeology; Pişkin, E., Marciniak, A., Bartkowiak, M., Eds.; Springer: Cham, Switzerland, 2018; pp. 181-198, ISBN 978-3-319-75081-1.

16. Vionis, A.K.; Papantoniou, G. Central place theory reloaded and revised. Land 2018, in submission.

17. Dikaios, P. La civilisation néolithique dans l'ile de Chypre. Syria 1936, 17, 356-364. [CrossRef]

18. Dikaios, P. Außerordentliche Sitzung. Montag, Den 21. September 1936. J. Ethnol. 1936, 68, 380-390.

19. Dikaios, P.; Seton-Williams, V.; Guest, E.M.; Rix, M. The excavations at Erimi, 1933-1935: Final Report. Rep. Dep. Antiq. Cyprus 1936, 1-81.

20. Knapp, A.B. The Archaeology of Cyprus: From Earliest Prehistory through the Bronze Age; Cambridge University Press: Cambridge, UK, 2013; ISBN 978-0-521-72347-3.

21. Steel, L. Cyprus before History. From the Earliest Settlers to the End of the Bronze Age; Duckworth: London, UK, 2004; ISBN 0-7156-3164-0.

22. Annual Report of the Director of the Department of Antiquities, Cyprus for the Year 2009; Department of Antiquities: Nicosia, Cyprus, 2013.

23. Georgiou, G. The Topography of Human Settlement in Cyprus in the Early and Middle Bronze Age. Ph.D. Thesis, University of Cyprus, Nicosia, Cyprus, 2007. (In Greek) 
24. Iacovou, M. Site size estimates and the diversity factor in Late Cypriot settlement histories. Bull. Am. Sch. Orient. Res. 2007, 348, 1-23.

25. Webb, J.M.; Frankel, D. Cultural regionalism and divergent social trajectories in Early Bronze Age Cyprus. Am. J. Archaeol. 2013, 117, 59-81. [CrossRef]

26. Webb, J.M. Shifting centres: Site location and resource procurement on the north coast of Cyprus over the longue durée of the Prehistoric Bronze Age. Land 2018, 7, 64. [CrossRef]

27. Mellink, M. Anatolian contacts with Chalcolithic Cyprus. Bull. Am. Sch. Orient. Res. 1991, 282, 167-175. [CrossRef]

28. Frankel, D.; Webb, J.M.; Croft, P. Marki Alonia: An Early and Middle Bronze Age Settlement in Cyprus. Excavations 1995-2000; Studies in Mediterranean Archaeology 123.2; Paul Åströms Förlag: Sävedalen, Sweden, 2006; ISBN 9789170812187.

29. Webb, J.M. The pottery. In Erimi Laonin tou Porakou. A Middle Bronze Age Community in Cyprus. Excavations 2008-2014; Studies in Mediterranean Archaeology 145; Bombardieri, L., Ed.; Paul Åströms Förlag: Uppsala, Sweden, 2017; pp. 129-205, ISBN 978-91-7081-227-9.

30. Webb, J.M. Ritual Architecture, Iconography and Practice in the Late Cypriot Bronze Age; Studies in Mediterranean Archaeology and Literature, Pocket-book 75; Paul Åström Förlag: Jonsered, Sweden, 1999; ISBN 91-7081-148-2.

31. Peltenburg, E. From isolation to state formation in Cyprus, ca. 3500-1500 B.C. In The Development of the Cypriot Economy from the Prehistoric Period to the Present Day; Karageorghis, V., Michaelides, D., Eds.; University of Cyprus and Bank of Cyprus: Nicosia, Cyprus, 1996; pp. 17-44, ISBN 9789963607105.

32. Keswani, P.S. Mortuary Ritual and Society in Bronze Age Cyprus; Equinox: London, UK, 2004; ISBN 1904768032.

33. Knapp, A.B. Prehistoric and Protohistoric Cyprus. Identity, Insularity and Connectivity; Oxford University Press: Oxford, UK, 2008; ISBN 9780199237371.

34. Georgiou, A. Cyprus during the 'Crisis Years' revisited. In The Mediterranean Mirror: Cultural Contacts in the Mediterranean Sea between 1200 and 750 B.C., International Post-Doc and Young Researcher Conference, Heidelberg, Germany, 6th-8th October 2012; Römisch-Germanischen Zentralmuseums Tagungen 20; Babbi, A., Bubenheimer-Erhart, F., Marin-Aguilera, B., Mühl, S., Eds.; Römisch-Germanischen Zentralmuseums: Mainz, Germany, 2015; pp. 129-145, ISBN 3795429854.

35. Manning, S.W.; Andreou, G.M.; Fisher, K.D.; Gerard-Little, P.; Kearns, C.; Leon, J.F.; Sewell, D.A.; Urban, T.M. Becoming urban: Investigating the anatomy of the Late Bronze Age complex, Maroni, Cyprus. J. Mediterr. Archaeol. 2014, 27, 3-32. [CrossRef]

36. Fisher, K.D. Making the first cities on Cyprus: Urbanism and social change in the Late Bronze Age. In Making Ancient Cities: Space and Place in Early Urban Societies Studies; Creekmore, A., Fisher, K.D., Eds.; Cambridge University Press: Cambridge, UK, 2014; pp. 181-219, ISBN 978-1107046528.

37. South, A.K.; Russel, P.; Keswani, P.S. Vasilikos Valley Project 3: Kalavasos-Ayios Dimitrios II, Ceramics, Objects, Tombs, Specialist Studies; Studies in Mediterranean Archaeology 71; Paul Åström Förlag: Göteborg, Sweden, 1989; ISBN 9186098853.

38. South, A.K. From pots to people, estimating population for Late Bronze Age Kalavasos. In Structure, Measurement and Meaning: Studies on Prehistoric Cyprus in Honour of David Frankel; Studies in Mediterranean Archaeology 143; Webb, J.M., Ed.; Paul Åström Förlag: Uppsala, Sweden, 2014; pp. 69-77, ISBN 978-91-981535-1-4.

39. Cadogan, G. Maroni: Change in Late Bronze Age Cyprus. In Late Bronze Age Settlement in Cyprus: Function and Relationship; Studies in Mediterranean Archaeology, Pocket-book 126; Åström, P., Herscher, E., Eds.; Paul Åström Förlag: Jonsered, Sweden, 1996; pp. 15-22, ISBN 9170811202.

40. Fisher, K.D. Elite place-making and social interaction in the Late Cypriot Bronze Age. J. Mediterr. Archaeol. 2009, 22, 183-209. [CrossRef]

41. Samaes, M.; Coenaerts, J. Exchange between southeastern Cyprus and the surrounding regions in the eastern Mediterranean during the Late Bronze Age. In Intercultural Contacts in the Ancient Mediterranean; Orientalia Lovaniensia Analecta 202; Duistermaat, K., Regulski, I., Eds.; Peeters Publishers: Leuven, Belgium, 2011; pp. 401-416, ISBN 978-90-429-2451-2.

42. Coenaerts, J.; Samaes, M. Rise, Peak and Fall. Towards an interpretation of site organisation in south-east Cyprus during the Late Bronze Age. In Cypriot Material Culture Studies from Picrolite Carving to Proskynetaria Analysis, Proceedings of the 8th Annual Postgraduate Cypriot Archaeology Conference Held in Honour of the Memory 
of Paul Åström, Brussel, Belgium, 27-29 November 2008; Jacobs, A., Cosyns, P., Eds.; Brussels University Press: Brussels, Belgium, 2015; pp. 65-92, ISBN 978-90-5487-974-9.

43. Iacovou, M. Cultural and political configurations in Iron Age Cyprus: The sequel to a protohistoric episode. Am. J. Archaeol. 2008, 112, 625-657. [CrossRef]

44. Iacovou, M. External and internal migrations during the 12th century BC. Setting the stage for an economically successful Early Iron Age in Cyprus. In Cyprus and the Aegean in the Early Iron Age-The Legacy of Nicolas Coldstream; Iacovou, M., Ed.; Bank of Cyprus Cultural Foundation: Nicosia, Cyprus, 2012; pp. 207-227, ISBN 978-9963-42-879-3.

45. Todd, I.A. Vasilikos Valley Project 12: The Field Survey of the Vasilikos Valley. Vol. 3, Human Settlement in the Vasilikos Valley; Studies in Mediterranean Archaeology 71.12; Paul Åströms Förlag: Uppsala, Sweden, 2013; ISBN 9170812519.

46. Georgiadou, A. Geometric-Archaic. In Vasilikos Valley Project 10: The Field Survey of the Vasilikos Valley. Vol. 2, Artefacts Recovered by the Field Survey. Studies in Mediterranean Archaeology 71.10; Todd, I.A., Ed.; Paul Åströms Förlag: Uppsala, Sweden, 2016; pp. 95-127, ISBN 978-91-7081-209-5.

47. Steel, L. Exploring Aredhiou: New light on the rural communities of the Cypriot hinterland during the Late Bronze Age. Am. J. Archaeol. 2016, 120, 511-536. [CrossRef]

48. Hadjicosti, M. The Late Bronze Age Tomb 2 from Mathiatis (New Perspectives for the Mathiatis Region). Rep. Dep. Antiq. Cyprus 1991, 75-91.

49. Muhly, J.D.; Maddin, R.; Wheeler, T.S. The oxhide ingots from Enkomi and Mathiati and Late Bronze Age copper smelting in Cyprus. Rep. Dep. Antiq. Cyprus 1980, 84-99.

50. Karageorghis, V.; Kenna, V.E.G.; Ducos, P. A Late Cypriote Tomb at Tamassos. Rep. Dep. Antiq. Cyprus 1965, 11-29.

51. Given, M.; Smith, J.S. Geometric to Classical landscapes. In The Sydney Cyprus Survey Project. Social Approaches to Regional Archaeological Survey; Monumenta Archaeologica Series 21; Given, M., Knapp, A.B., Eds.; Cotsen Institute of Archaeology, University of California: Los Angeles, CA, USA, 2003; pp. 270-277, ISBN 978-1-931745-04-8.

52. Iacovou, M. (Ed.) Archaeological Field Survey in Cyprus. Past History, Future Potentials. Proceedings of a Conference Held by the Archaeological Research Unit of the University of Cyprus, 1-2 December 2000; British School at Athens Studies 11; The British School at Athens: London, UK, 2004; ISBN 9780904887464.

53. Rautman, M. Classical-Late Roman periods. In Vasilikos Valley Project 10: The Field Survey of the Vasilikos Valley. Vol. 2, Artefacts Recovered by the Field Survey. Studies in Mediterranean Archaeology 71.10; Todd, I.A., Ed.; Paul Åströms Förlag: Uppsala, Sweden, 2016; pp. 129-158, ISBN 978-91-7081-209-5.

54. Georgiadou, A. The Vasilikos valley within the Amathusian territory in the Iron Age: Settlement patterns and inequalities. In Structures of Inequality on Bronze Age Cyprus. Studies in Honour of Alison K.South; Studies in Mediterranean Archaeology 187; Hulin, L., Crewe, L., Webb, J., Eds.; Paul Åströms Förlag: Uppsala, Sweden, 2018; pp. 155-167, ISBN 978-9925-7455-0-0.

55. Papantoniou, G. Religion and Social Transformations in Cyprus. From the Cypriot Basileis to the Hellenistic Strategos; Mnemosyne Supplements 347; Brill: Leiden, The Netherlands, 2012; ISBN 978-90-04-23380-5.

56. Christodoulou, D. The Evolution of the Rural Land Use Pattern in Cyprus; Geographical Publications Limited: London, UK, 1959; ISBN 0900394064.

57. Kassianidou, V. The exploitation of the landscape: Metal resources and the copper trade during the Age of the Cypriot city-kingdoms. Bull. Am. Sch. Orient. Res. 2013, 370, 49-82. [CrossRef]

58. Markou, F. Sites and Uses of the Hydrological Zones of the Tremithos and Pouzis Rivers from the Early Bronze Age to the Roman Period: Surface and Archival Survey. Master's Thesis, University of Cyprus, Nicosia, Cyprus, 2013. (In Greek)

59. Fasnacht, W. Dynamique de la production de cuivre au temps de royaumes de Chypre. Cahiers du Centre d'Études Chypriotes 2002, 32, 209-218. [CrossRef]

60. Papantoniou, G. Cyprus from basileis to strategos: A sacred-landscapes approach. Am. J. Archaeol. 2013, 117, 33-57. [CrossRef]

61. Masson, O.; Hermary, A. La géographie des royaumes chypriotes chez les modernes. Cahiers du Centre d'Études Chypriotes 1992, 17, 23-28. [CrossRef]

62. Mitford, T.B. Roman Cyprus. In Aufstieg und Niedergang der römischen Welt 2(7.2); Temporini, H., Ed.; de Gruyter: Berlin, Germany, 1980; pp. 1285-1384, ISBN 9783110860429. 
63. Aupert, P. L'histoire des fouilles. In Guide d'Amathonte; Sites et monuments 15; Aupert, P., Ed.; École Française d'Athènes/The A.G. Leventis Foundation: Athens, Greece, 1996; pp. 13-15, ISBN 9963-42-081-8.

64. Sergidis, C. Limassol until Ottoman Period; Panikos Mavrelis Foundation: Limassol, Cyprus, 2003; ISBN 9963-88-30-0-1. (In Greek)

65. Heitz, C.; Stapfer, R. (Eds.) Mobility and Pottery Production, Archaeological and Anthropological Perspectives; Sidestone Press: Leiden, The Netherlands, 2017; ISBN 9789088904608.

66. Rupp, D.W. Vive le roi: The emergence of the state in Iron Age Cyprus. In Western Cyprus: Connections; Studies in Mediterranean Archaeology 77; Rupp, D.W., Ed.; Paul Åströms Forlag: Göteborg, Sweden, 1987; pp. 147-161, ISBN 9186098578.

67. Hermary, A. Musée du Louvre, Département des antiquités orientales: Catalogue des antiquités de Chypre. Sculptures; Réunion des Musées Nationaux: Paris, France, 1989; ISBN 2-7118-2279-6.

68. Hermary, A. Amathonte II: Testimonia 2. La Sculpture; Études chypriotes 5/Recherche sur les grandes civilisations. Mémoire 10; Éditions A.D.P.F./École Française d'Athènes: Paris, France, 1981; ISBN 0241-3996.

69. Hermary, A. Amathonte V: Les figurines en terre cuite archä̈ques et classiques. Les sculptures en pierre; Études chypriotes 15; École Française d'Athènes/The A.G. Leventis Foundation: Athens, Greece; Nicosia, Cyprus, 2000; ISBN 978-2-86958-156-2.

70. Papantoniou, G.; Bourogiannis, G. The Cypriot extra-urban sanctuary as a central place: The case of Agia Irini. Land 2018, 7, 139. [CrossRef]

71. Hackett, J. A History of the Orthodox Church of Cyprus from the Coming of the Apostles Paul and Barnabas to the Commencement of the British occupation (A.D. 45-A.D. 1878) together with Some Account of the Latin and Other Churches Existing in the Island; Methuen \& Co.: London, UK, 1901.

72. Gunnis, R. Historic Cyprus: A Guide to Its Towns and Villages, Monasteries and Castles; K. Rustem \& Bro.: Nicosia, Cyprus, 1936.

73. Holy Monastery of Stavrovouni. History, Architecture, Heirlooms; Publications of Holy Monastery of Stavrovouni: Nicosia, Cyprus, 1998; ISBN 9963-615-02-3. (In Greek)

74. Athenaiou, A. Stavrovouni. The Sacred Mountain of Cyprus; Kalokathi Publications: Athens, Greece, 2017; ISBN 9789603967835. (In Greek)

75. Gordon, J.M. Between Alexandria and Rome: A Postcolonial Archaeology of Cultural Identity in Hellenistic and Roman Cyprus. Ph.D. Thesis, University of Cincinnati, Cincinnati, OH, USA, 2012.

76. Rautman, M. From polytheism to Christianity in the temples of Cyprus. In Ancient Journeys. A Festschrift in Honour of Eugene Numa Lane. Callaway, C., Ed.; The STOA, 2001. Available online: http:/ / www.stoa. org/hopper/text.jsp?doc=Stoa:text:2001.01.0014 (accessed on 29 September 2018).

77. Vionis, A.K. Settled and sacred landscapes of Cyprus: The relationship of church and landscape in Byzantine Kofinou. In Church Building in Cyprus (4th to 7th Centuries): A Mirror of Intercultural Contacts in the Eastern Mediterranean; Schriften des Instituts für Interdiziplinäre Zypern-Studien 12; Rogge, S., Nicolaou, D., Horster, M., Eds.; Waxmann: Münster, Germany, 2016; pp. 45-70, ISBN 3830937911.

78. Vionis, A.K.; Papantoniou, G. Sacred landscapes as economic central places in Late Antique Naxos and Cyprus. Antiq. Tardive 2017, 25, 263-286. [CrossRef]

79. Hadjisavvas, S. Olive Oil Processing in Cyprus from the Bronze Age to the Byzantine Period; Studies in Mediterranean Archaeology 99; Paul Åströms Förlag: Nicosia, Cyprus, 1992; ISBN 9170810338.

80. Hadjisavvas, S. The economy of the olive. In The Development of the Cypriot Economy. From the Prehistoric Period to the Present Day; Karageorghis, V., Michaelides, D., Eds.; The A.G. Leventis Foundation/Bank of Cyprus: Nicosia, Cyprus, 1996; pp. 127-138, ISBN 9963-607-10-1.

81. Vionis, A.K.; Papantoniou, G. Economic landscapes and transformed mindscapes in Cyprus from Roman times to the Early Middle Ages. In Change and Resilience: The Occupation of Mediterranean Islands in Late Antiquity; Cau Ontiveros, M.A., Mas Florit, C., Eds.; Oxbow: Oxford, UK, in press.

82. Knitter, D. Central Places and the Environment. Investigations of an Interdependent Relationship. Ph.D. Thesis, Free University, Berlin, Germany, 2013.

83. Iacovou, M. Political economies and landscape transformations: The case of ancient Paphos. In Structure, Measurement, and Meaning: Studies on Prehistoric Cyprus in Honour of David Frankel; Studies in Mediterranean Archaeology 143; Webb, J.M., Ed.; Paul Åströms Forlag: Uppsala, Sweden, 2014; pp. 161-174, ISBN 978-91-981535-1-4. 
84. Kearns, C. Re-survey and spatial analysis of landscape developments during the first millennium BC on Cyprus. Antiquity 2016, 90, 353. [CrossRef]

85. Casarott, A.; Pelgrom, J.; Stek, T.D. A systematic GIS-based analysis of settlement developments in the landscape of Venusia in the Hellenistic-Roman period. Archaeol. Anthropol. Sci. 2017. [CrossRef]

86. Given, M. The precarious conviviality of water mills. Archaeol. Dialogues 2018, 25, 71-94. [CrossRef] 